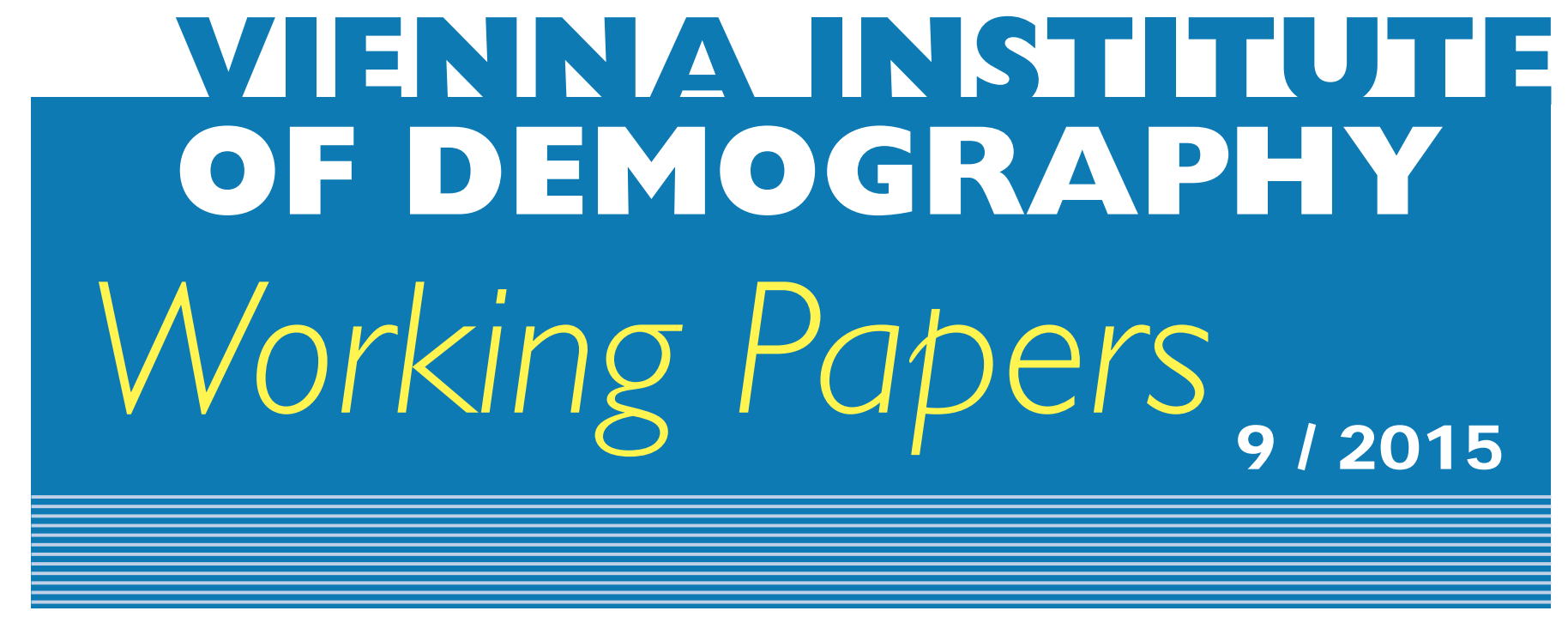

Roman H offmann and Raya Muttarak

\title{
A Tale of Disaster Experience in Two Countries: Does Education Promote Disaster Preparedness in the Philippines and Thailand
}

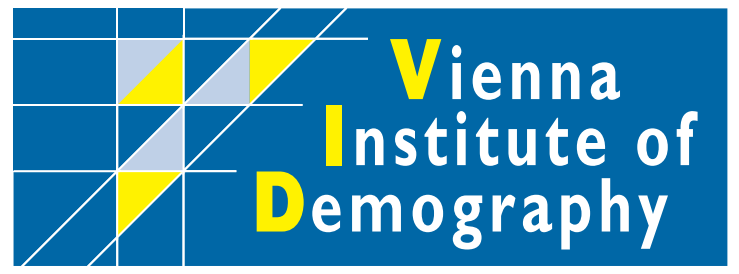

Vienna Institute of Demography Austrian Academy of Sciences

Welthandelsplatz 2 / Level 2

A-I020Vienna A Austria

E-Mail:vid@oeaw.ac.at

Website: www.oeaw.ac.at/vid

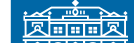

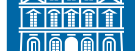

OAN Austrian Academy of Sciences 


\begin{abstract}
Preparing for a disaster can substantially minimize loss and damages from natural hazards. Amongst other socio-demographic determinants, disaster experience and education are found to be key predictors of individual disaster preparedness. This paper explores the pathways through which education enhances disaster preparedness and the interplay between education and experience in shaping preparedness behaviours. Data analysis is based on face-to-face interviews in two disaster-prone countries: the Philippines and Thailand. While education raises the propensity to prepare against disasters, we further find that the effect of education on disaster preparedness is mainly mediated through social capital and disaster risk perception in Thailand but there is no evidence that education is mediated through other observable channels in the Philippines. This in turn suggests that the underlying mechanisms explaining the education effects are highly context-specific. Furthermore, we show that education raises disaster preparedness only for the households that have not been affected by a disaster in the past. One explanation could be that education improves abstract reasoning and anticipation skills such that the better educated undertake preventive measures without needing to first experience the harmful event and then learn later.
\end{abstract}

\title{
Keywords
}

Disaster experience, disaster preparedness, education, mediating factors, Philippines, Thailand

\section{Authors}

Roman Hoffmann, Department of Economic Sociology, University of Vienna, Vienna. Email: roman.hoffman@univie.ac.at

Raya Muttarak, Wittgenstein Centre for Demography and Global Human Capital (IIASA, VID/ÖAW, WU). Email: raya.muttarak@,oeaw.ac.at

\section{Acknowledgements}

This work was made possible by an advanced grant of the European Research Council, "Forecasting Societies Adaptive Capacities to Climate Change" (grant agreement ERC-2008-AdG 230195 FutureSoc); Ratchadaphiseksomphot Endowment Fund of Chulalongkorn University for the project "Understanding Social Barriers to Coping with and Adapting to Extreme Climate Events" (grant agreement number: RES560530150-CC). The project in the Philippines was funded with a research grant from the Vienna University of Economics and Business. The authors would like to gratefully thank their partners in the Philippines and Thailand, most notably the Kasagana-Ka Development Center Inc. (PH) represented by Ms. Maria-Anna Ignacio and the College of Population Studies, Chulalongkorn University in particular Dr.Wiraporn Pothisiri (TH), who supported us with the data collection. 


\title{
A Tale of Disaster Experience in Two Countries: Does Education Promote Disaster Preparedness in the Philippines and Thailand?
}

\author{
Roman Hoffmann and Raya Muttarak
}

\section{Introduction}

In the past years the world has witnessed a significant global increase in the intensity and frequency of extreme weather events such as floods, droughts and tropical storms, which are expected to increase even further in a future warmer climate (Field et al. 2012). Since 1975, the number of reported disaster incidents has risen more than threefold: from 65 reported incidents in 1975 to 344 in 2014. In the year 2014 alone, disasters caused a worldwide damage of US\$ 98.43 billion with more than 140 million persons affected (EMDAT statistics 2015; Centre for Research on the Epidemiology of Disasters 2015). Heavily exposed low- and middle-income countries, in particular, carry a large share of the human and economic burden. The lack of resources for early warning systems, poor building regulations, unplanned squatter developments and lack of relief infrastructure and resources are responsible for higher disaster losses in these countries.

Recently, there has been improvement in national disaster risk reduction efforts in particular after major disaster events such as the 2004 Indian Ocean Tsunami (Birkmann et al. 2008) or the 2013 Typhoon Haiyan in the Philippines. Indeed, government's investment in structural mitigation for large buildings or infrastructure, implementation of early warning systems, planned evacuation routes and shelters are effective in preventing loss of life (Andrews \& Quintana 2015). Nevertheless, disaster risk reduction measures at the national level alone are not sufficient to protect households from the devastating impacts of a disaster. In fact, in time of emergencies - be natural disasters or terrorist attacks - experts recommend the "72 Hour Rule" in which individuals are required to be self-sufficient for at least three days following a disaster. This is because it takes some time for local government and disaster-relief organizations to mobilise resources to an affected area. Therefore, individual preparedness measures such as stockpiling of food and water, having a first aid kit in the home, or having a family evacuation plan can ensure a proper response to the hazards. Particularly in low- and middle-income countries context where public disaster risk management is relatively underdeveloped, precautionary measures taken by households before a disaster occurs can reduce the risk of loss of life and injuries as well as minimise damage to the property.

Despite the importance of individual preparedness, several studies report relatively low levels of disaster preparedness even in disaster prone areas (Adiyoso \& Kanegae 2014; Kohn et al. 2012). Indeed, how people can be motivated to take precautionary action if they have little prior disaster experience has been a fundamental question raised by scholars of risk analysis and risk communication (Harvatt et al. 2011). Accordingly, in many disaster-prone areas 
local and national government and NGOs have put efforts in providing disaster educational programmes and emergency training in order to raise awareness, promote self-reliance and household preparedness action-taking. While such educational activities can boost disaster preparedness in some cases (Wood et al. 2012; Mishra \& Suar 2007) with relatively small enhancement effects (Tanaka 2005), many other studies have documented the failure of these campaigns in initiating protective actions (Baker 1980; Paton \& Johnston 2001; Sims \& Baumann 1983; Sorensen 1983). In order to promote household disaster preparedness, it is thus crucial to understand underlying factors explaining the adoption of preparedness measures. There are nevertheless relatively few empirical studies on disaster preparedness in developing countries (Muttarak \& Pothisiri 2013).

To this end, this study focuses on examining individual determinants of disaster preparedness in low- and middle-income countries in Southeast Asia, namely, the Philippines and Thailand. Both countries have been affected by major disaster incidents in the past decade. Such disaster experience may raise public awareness and preparedness accordingly. In this paper, we aim to: 1) analyse the role of education in shaping an individual's propensity to prepare against disasters and identify mediating channels through which education may influence disaster preparedness; and 2) investigate the importance of past disaster experience and its interplay with education. Theoretically, both factors may determine preparedness through similar mechanisms such as increasing risk perception or knowledge about the devastating consequences of a disaster. Formal education, as an alternative channel through which individuals "learn" about disaster risks and preventive strategies, may consequently replace disaster experience in promoting preparedness actions.

The remainder of the paper is structured as follows. Section 2 describes determinants of disaster preparedness, presents a conceptual framework for our empirical analysis and discusses previous literature on education and preparedness behaviour. Section 3 introduces the case studies and presents the data and measurement used including the estimation strategy. The descriptive and multivariate results are presented and discussed in section 4 . Section 5 concludes with a summary of the findings and implications of our research.

\section{Conceptual Framework and Previous Literature}

\subsection{Overview of Determinants of Individual Disaster Preparedness}

The previous literature has identified various determinants of personal/household disaster preparedness. These can be broadly divided into socio-demographic characteristics, structural/geographical variables and psychosocial factors. In terms of demographic characteristics, generally being married (Reininger et al. 2013; Russell et al. 1995) in middle-age groups (Baker 2011; Boscarino et al. 2006; Sattler et al. 2000) and having children living in the home (Basolo et al. 2009; Eisenman et al. 2009) are associated with higher preparedness actions. Likewise, having household members with a disability or health conditions that require special equipment also increases the likelihood of preparedness (Ablah et al. 2009; Eisenman et al. 
2009; Muttarak \& Pothisiri 2013). Meanwhile, the findings on how gender and race/ethnicity are related to preparedness actions are inconsistent, with many studies reported no associations (Bourque et al. 2012; Kim \& Kang 2010; Lindell \& Hwang 2008).

While demographic characteristics determine necessities to prepare (e.g., having dependent members in the home), socioeconomic factors influence a household's capability to undertake preparedness actions, among other things. Some preparedness measures such as purchasing disaster insurance or the technical or structural building retrofitting require financial investment. Thus, higher income is associated with higher preparedness levels partly because it enable households to afford to take such actions (Mishra \& Suar 2007; Murphy et al. 2009; Phillips et al. 2005). Furthermore, homeowners are more likely to be prepared than renters (Burby et al. 2003; Siegel et al. 2003; Spittal et al. 2008). Having invested more time and money in constructing their homes and household goods, home owners have stronger ties with the property and place of residence as well as greater knowledge of options for action while those who rent are more mobile and less focused on the long-term horizon (Harvatt et al. 2011). Socioeconomic constraints thus partially explain the adoption of preparedness actions.

Structural/geographical variables have also been identified to be crucial determinants of disaster preparedness. Longer residence in the community enhances local knowledge about the neighbourhood, natural environment and hazard risks, emergency organisations and such. This in turn increases disaster awareness and promotes the undertaking of preparatory activities likewise (Tanaka 2005). Similarly, living in disaster prone area is also found to be positively associated with preparedness efforts (Baker 2011). Living in or close to the hazard area implies better knowledge about hazard risk and consequently increases preparedness actions (Lindell \& Hwang 2008).

Apart from demographic, socioeconomic and structural/geographical characteristics determining the need and capacity to be prepared, preparedness has also been found to be associated with psychosocial factors including hazard awareness, risk perception, self-efficacy and knowledge. In order for preparedness actions to take place, first people need to be aware of the hazards and consequently perceive such hazards as critical or salient issues within their community. Accordingly, some studies reported that higher levels of perceived risk i.e. perceived likelihood of the hazard occurring and perceived severity of the hazard if it does occur are associated with increases in preparedness behaviour (Martin et al. 2009; McNeill et al. 2013; Paul \& Bhuiyan 2010). On the other hand, lack of self-efficacy i.e. beliefs regarding personal capacity to act effectively can inhibit individuals to take actions (Lindell \& Whitney 2000; Paton et al. 2001). Recognising the role of psychosocial factors is thus fundamental in public campaign to promote personal disaster preparedness. 


\subsection{Conceptual Framework: the Role of Education in Promoting Preparedness}

Apart from the above mentioned factors, in this study, we contend that formal education can play a key role in promoting preparedness behaviour. In fact, the argument that education can have positive externalities on life outcomes is not new. One well-established example is the link between education and health (Grossman 2006; Brunello et al. 2015; Gathmann et al. 2014). Building upon previous studies on the returns to education, in particular for health and well-being, we draw the schematic diagram depicting different mechanisms through which education may influence disaster preparedness behaviour (box i) as shown in Figure 1. In addition, Figure 1 also illustrates the relationship between preparedness and disaster experience (box ii), another key driver of preparedness actions.

(i)

(ii)

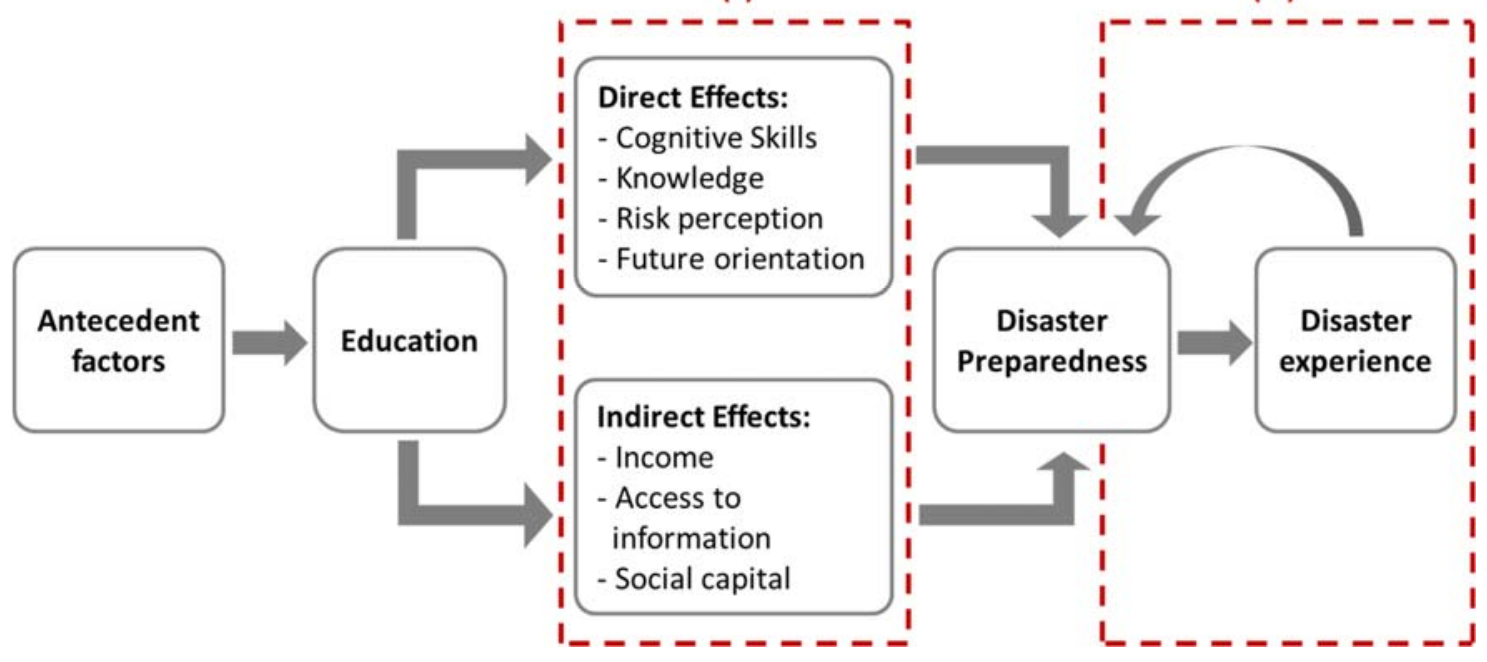

Figure 1: Flowchart explaining how education influences disaster preparedness and its interplay with disaster experience

Education, which in itself is influenced by different antecedent factors such as family background, genetic traits and abilities, can contribute to preparedness actions in direct and indirect manners. ${ }^{1}$ First, directly formal schooling is a primary way individuals acquire knowledge, skills, and competencies that can influence their preparatory efforts. There is established scientific evidence showing that cognitive activities during schooling such as solving mathematical problems can have long-lasting effects on neurological functioning (Eslinger et al. 2009; Quartz \& Sejnowski 1997) as well as on the synoptic brain structure (Kandel 2007).

\footnotetext{
${ }^{1}$ Although it is possible that these antecedent factors can also influence disaster preparedness and the effect of education on preparedness then becomes spurious, it is reasonable to assume that education does have net effects on preparedness behaviour in a similar way as the causal claim regarding the effect of education on health.
} 
Schooling provides a unique environment to engage in cognitive activities such as learning to read, write and use numbers. As students move to higher grades, cognitive skills required in school become more progressively demanding and involve meta-cognitive skills such as categorization, logical deduction and knowledge transfers (Blair et al. 2005; Ceci 1991; Nisbett 2010). This abstract cognitive exercise alters the way educated individuals think, reason and solve problems likewise (Baker et al. 2011). Indeed, experimental studies have shown that higher-order cognition improves risk assessment and decision making skills (de Bruin et al. 2007; Peters et al. 2006). These are relevant components of reasoning related to risk perception and making choices about preparedness actions.

Furthermore, education enhances the acquisition of knowledge, values and priorities as well as the capacity to plan for the future and efficiency in allocation of resources (Cutler \& Lleras-Muney 2010; Kenkel 1991). Schooling can help individuals adopt preparatory measures by improving their knowledge of the relationship between preparedness and disaster risk reduction. Moreover, educated individuals may have better understanding of what preparedness measures to take. Recent evidence also shows that education may change time preferences such that more educated people are more patient, more goal-oriented and thus make more investments in e.g., financial, health or education for their future (Chew et al. 2010; Oreopoulos \& Salvanes 2011; Pérez-Arce 2011). This could hence influence adoption of such precautionary measures which require long term investments as purchasing disaster insurance.

In addition, indirectly the effect of education on preparedness behaviour can be mediated by other factors including income, access to information and social capital. Needless to say income is one major returns to education (Card 1999). The increased income afforded by high levels of education enables individuals to undertake costly preparatory measures such as purchasing disaster insurance or flood protection devices accordingly. Moreover, many empirical studies have shown that people with more years of formal education have access to more sources and types of information (Cotten \& Gupta 2004; Neuenschwander et al. 2012; Wen et al. 2011). The more educated are found to be better informed and subsequently more likely to make use of new information such as the danger of smoking or HIV/AIDS-related information first (de Walque 2007b; de Walque 2010). The level of education is not only highly correlated with access to weather forecasts and warnings but the highly educated are also able to understand more complex environmental issues such as climate change better than less educated counterparts (Rodriguez et al. 2007; Xiao \& McCright 2007). Subsequently, access to forecast and early warnings allow individuals to respond and prepare for the hazards appropriately.

Another important channel through which education may increase preparedness activities is via social networks given that more educated individuals are commonly found to have higher social capital (Huang et al. 2009; Lake \& Huckfeldt 1998). Social capital here refers to embeddedness in relationships or the social structure in a community. The perception of risk and motivations to take preventive action can be transferred via social networks while individuals who participate regularly in social activities can benefit from an exchange of useful information and warnings. Indeed, there is evidence that social participation, strong family and 
community networks and high level of trust are positively associated with preparedness behaviour (Kirschenbaum 2006; Solberg et al. 2010; Witvorapong et al. 2015).

The above mentioned mechanisms suggest that education can increase preparedness behaviour through direct and indirect channels. Nevertheless, empirical evidence from previous literature on the relationship between education level and disaster preparedness is not consistent. On the one hand, many studies reported that higher educational attainment enhances preparedness including being prepared for earthquakes (Russell et al. 1995), hurricanes (Norris et al. 1999; Baker et al. 2011; Reininger et al. 2013), floods (Lave \& Lave 1991; Thieken et al. 2007), tsunami (Muttarak \& Pothisiri 2013), terrorism (Lee \& Lemyre 2009; Bourque et al. 2012; Eisenman et al. 2009) and general emergency preparedness (Al-Rousan et al. 2014; Smith \& Notaro 2009). On the other hand, a considerable number of studies reported no association between education and preparedness (Faupel et al. 1992; Hausman et al. 2007; Heller et al. 2005; Jackson 1981; Miceli et al. 2008; Kim \& Kang 2010; Lee \& Lemyre 2009; Lindell \& Hwang 2008; Siegel et al. 2003; Spittal et al. 2008). The discrepancy in the findings can be due to different measurement of preparedness, disaster types, research designs and geographical contexts.

Furthermore, to our knowledge, none of these studies have empirically identified the underlying mechanisms through which education influences preparedness behaviours. In this study, we investigate whether education plays a role in promoting preparedness actions and how i.e. through which channel education influences disaster preparedness.

\subsection{Disaster Experience and its Interplay with Education}

Besides education, previous disaster experience is one key factor determining preparedness behaviour. Based on our conceptual framework shown in Figure 1, disaster preparedness is promoted through education and disaster experience. Education raises disaster preparedness which in turn reduces the likelihood of being affected by a disaster. Similarly, the households which have experienced loss and damages from disasters in the past learnt about potential harmful impacts of disasters and consequently become better prepared for future disaster events. Indeed, many studies have shown that people who have experienced floods (Bubeck et al. 2013; Lawrence et al. 2014; Siegrist \& Gutscher 2008; Lindell \& Hwang 2008), earthquakes (Mileti et al. 1992; Tekeli-Yeşil et al. 2010), hurricanes (Horney et al. 2008; Sattler et al. 2000) and wildfires (McGee \& Russell 2003) are more likely to prepare for a future event. ${ }^{2}$

\footnotetext{
${ }^{2}$ Note, however, that some studies found no or marginal association between previous experience and household preparedness (Basolo et al. 2009; Mileti \& Darlington 1995; Mileti \& O’Brien 1992; Rincon et al. 2001). In fact, the association between experience and preparedness depends on how experience is measured. The effect of past experience on preparedness behaviour varies with hazard context, individual and the circumstances of the experience (Kellens et al. 2013). In general, precautionary action is found to increase with intensity of the impacts (e.g., damage, injury, death or other losses) and severity of damage experienced and when the experience is more recent (Heller et al. 2005; Nguyen et al. 2006; Siegel et al. 2003).
} 
Theoretically, previous disaster experience may influence preparedness behaviour through channels similar to education. Hazard awareness and risk perception, for example, are closely related to prior disaster experience since direct disaster experience can increase awareness and understanding of risks, perceived consequences of the disaster and intentions to take precautionary measures. Having been and surviving a disaster may increase awareness about the potential for destruction, demonstrate benefits of preparation and evacuation, and enhance knowledge on how to recover in its aftermath as well as how to cope with subsequent disaster threats (Sattler et al. 2000). This in turn increases preparedness behaviour likewise.

While disaster experience appears to be a key driver of disaster preparedness behaviour, certainly it is not an ideal way to promote household/individual adoption of precautionary measures. The fundamental question hence is how to increase risk awareness for people who have not been affected by disasters so far. Here we argue that education can substitute disaster experience such that highly educated individuals can understand the disaster risks and anticipate the impacts without first-hand experience. Therefore, we are interested in the interplay between disaster experience and education in shaping preparedness behaviour.

\section{Research Design and Methods}

\subsection{Study Areas: The Philippines and Thailand}

Data from two Southeast Asian Countries, the Philippines (PH) and Thailand (TH) are employed for the analysis. With diverse socio-economic background of the populations and different exposure to disaster risk, the two countries represent well-suited cases for this study. Lying along the Pacific Typhoon Belt and being within the Pacific Ring of Fire, the Philippines is highly exposed to natural hazards: from violent volcanic and earthquake activities to tropical cyclones. Meanwhile, Thailand's 3,219 km of coastline is prone to tsunami and storm surge whereas low-lying inland areas are vulnerable to flood. The survey data used in both countries were collected by the authors allowing us to tailor the research instruments to our research questions.

The data for the Philippines were collected in Masinag, Batasan, and Montalban, three low-income communities in Metro Manila and the nearby province of Rizal with a rural, periurban population. The three study areas have been frequently affected by natural calamities in the past with devastating consequences for the local communities. Primarily, these areas are exposed to risks of floods, landslides and storm damages caused by numerous typhoons that hit the country with an average of 20 tropical storms per year (Brower et al. 2014). Furthermore, all three areas have a significant earthquake hazard as they are located at close range of the Marikina Valley Fault System. Interviews were conducted with randomly selected female members of a social development organization operating in Metro Manila and the surrounding areas. In most cases, the respondents were female household heads and hence were able to give information about preparedness measures undertaken by the household. The data was 
collected using face-to-face interviews in February 2014. In total, 889 respondents (aged 20 to 75 years) were interviewed based on standardized questionnaires.

The Thai data were obtained from a representative household survey of three provinces, namely, Phang Nga, Kalasin, and Ayutthaya. The survey was conducted based on a stratified two-stage sample design with villages and housing blocks as primary sampling units. In stage two, a random sample of $25 \%$ of districts in the selected provinces, $25 \%$ of villages in the selected districts and $25 \%$ of households in the selected villages was drawn for interview. Like in the Philippines, the study areas in Thailand are exposed to increased natural hazards. The province of Phang Nga, located along the Indian Ocean coastline, was strongly affected by the 2004 Asian Tsunami with 4,224 deaths accounting for $78 \%$ of the death toll from the 2004 tsunami in the country. The interior province of Ayutthaya is situated on the low-lying area in the Central plains and is exposed to frequent flooding. Kalasin is located in the northeast and is particularly prone to drought but floods and windstorms are also not uncommon. Interviews were conducted face-to-face with one male or female member aged 15 or above from each household. The survey was conducted between May - August 2013 with 1,310 respondents participated in the study.
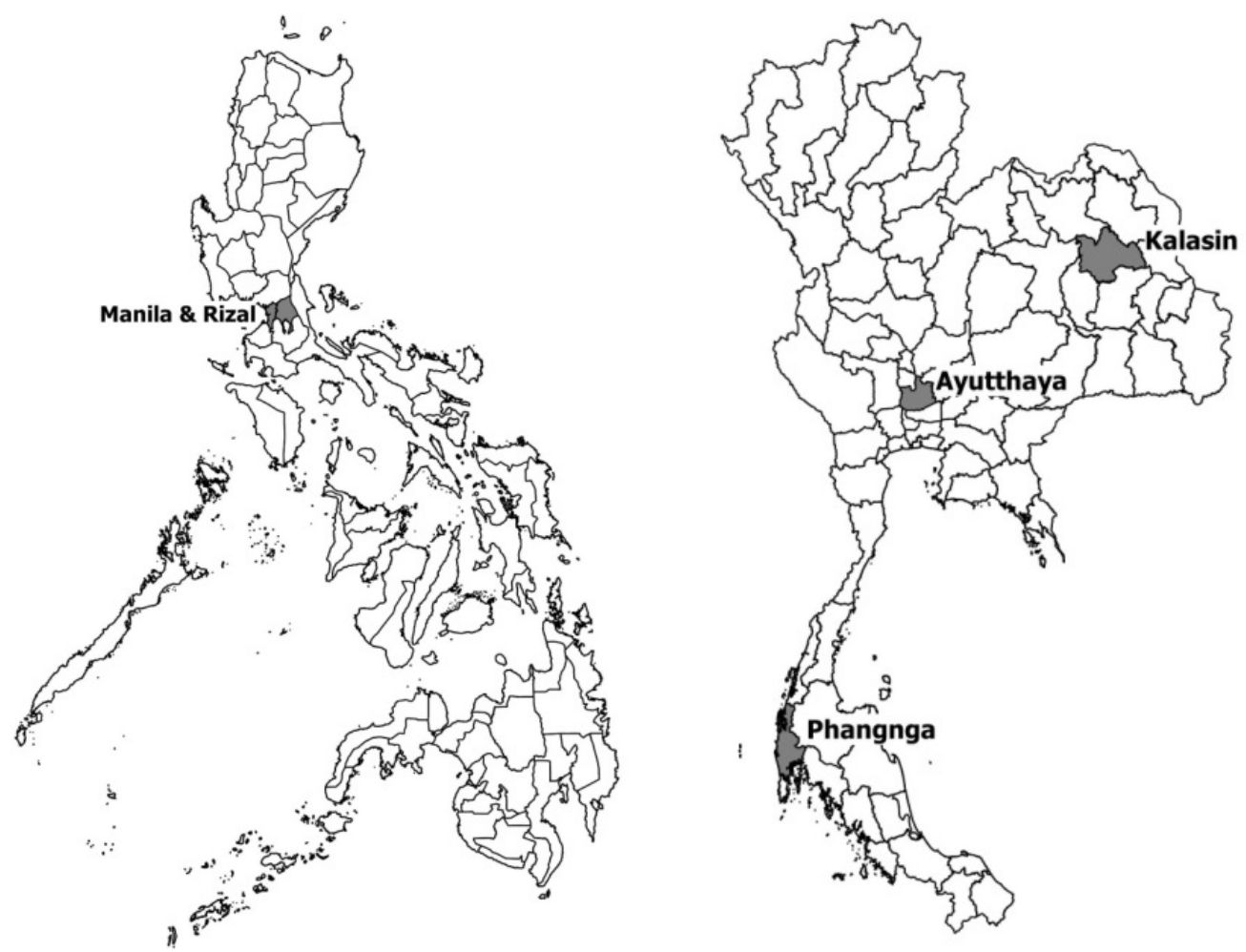

Figure 2: Map of study areas in Philippines and Thailand 


\subsection{Measurement}

The paper aims to explore the role of education, disaster experience and a set of potential mediating factors in explaining a person's tendency to undertake preparedness measures. The variables used in the analysis and their measurement are described below.

\subsubsection{Dependent Variables}

Disaster preparedness is measured in two steps. The first outcome is a binary variable coded one if the household has taken any preparedness measure against disasters; zero otherwise. If so, secondly, the respondents were asked to identify all precautionary measures that were undertaken. The answers are categorised into five categories (none, one, two, three, four, and five or more preparedness measures). The resulting ordinal variable - the number of preparedness measures taken -allows us to consider not only whether a household was prepared at the time of the surveys, but also to what extent. Furthermore, using both measures, we are able to test for the robustness of our findings.

\subsubsection{Explanatory Variables}

Education is measured as years of schooling up to tertiary education (college, university, vocational training, etc.) in the Philippines. In Thailand, detailed categories of the respondents' highest level of education are used to construct the variable year of schooling. Disaster experience is measured as a dummy variable which takes the value one if the household has been affected by a natural disaster in the past 3 years. Those who experienced housing damages, damages to livelihoods and/or injuries or loss of household members are defined as being affected by a disaster.

\subsubsection{Mediating Factors}

Household income per capita, our first potential mediating factor, is a measure of economic resources. The income variable measured in local currency is rescaled (divided by 1000). Cognitive skills are measured using a word recall test where respondents were read a list of ten simple nouns and asked to promptly repeat as many of those words as possible in any order. Although word recall is designed to estimate episodic memory abilities, it has been shown to be strongly correlated with cognitive abilities (Oberauer et al. 2000).

In the Philippines, we additionally test for future orientation (time preference) based on a hypothetical choice set. Respondents were asked a series of questions in which they had to choose between receiving a fix amount of 10,000PHP $(\sim 220 \$)$ in one year or a gradually decreasing amount immediately (Benzion et al. 1989; Shelley 1993). A person's future orientation is approximated based on his/her willingness to wait for the larger amount. Taking preparedness actions involve immediate costs and delayed benefits. People with future-oriented time preferences thus should be more likely to adopt preparedness measures since they value future outcomes more than immediate ones. In addition, we measure risk preference using a self-assessment test of a person's general willingness to take risks (Dohmen et al. 2011). Atti- 
tudes toward risk can potentially be related to adoption of preventive measures such as purchasing of disaster insurance to insure against catastrophic events.

In Thailand, we assess disaster risk perception by asking the respondents to estimate the possibility of major disasters in a community in the next five years given the choice: very unlikely, somewhat unlikely, somewhat likely and very likely. Moreover, the respondents were also asked about climate change perception i.e. how they perceive the impact of climate change on their family (very weak, weak, moderate, strong and very strong).

Finally, we consider the role of social capital in both countries. Note that the measurement of social capital differs in the two countries due to different questions used in the surveys. In the Philippines, social capital is measured as access to help in the neighbourhood. In Thailand, voluntary participation in community activities is used as a proxy for social capital. The former denotes social support available while the latter represents embeddedness in social networks.

\subsubsection{Control Variables}

Furthermore, a set of additional variables that have been shown to be relevant in the literature are accounted for. We control for socio-demographic and household characteristics including age, sex (TH only), years of residence in the neighbourhood ( $\mathrm{PH})$ or in the household (TH) in years, marital status, employment status, health status based on a subjective health rating, household size, proportion of children aged $\leq 5$ and proportion of older persons aged $\geq 65$ in the household and proportion of household members with at least secondary education. For geographical characteristics potentially related to exposure to natural hazards, community dummies and information about whether the household is located near a river $(<200 \mathrm{~m})$, near the sea $(<1 \mathrm{~km})$ or near a mountain $(<200 \mathrm{~m})$ are controlled for.

In the Philippines, there is additional information on parental education. Parental education background is measured with two dummy variables that indicate whether the mother and/or the father have obtained some secondary education. In addition, dummies that take the value one if the mother or father died early or was unknown to the child are added. This procedure allows us to minimise sample drop-outs due to missing values on the parental education variables. In Thailand, control for housing and land tenure i.e. whether the household owns the house and land where the family lives are also included. Table 1 presents the summary statistics of all variables used in the analysis including additional information on their measurement. 
Table 1: Measurement and summary statistics for dependent and independent variables

\begin{tabular}{|c|c|c|c|c|c|c|}
\hline & \multicolumn{3}{|c|}{ Philippines } & \multicolumn{3}{|c|}{ Thailand } \\
\hline & Range & Mean & SD & Range & Mean & SD \\
\hline \multicolumn{7}{|l|}{ Outcome variables } \\
\hline Has taken preparedness action & $0 / 1$ & 0.77 & $(0.42)$ & $0 / 1$ & 0.31 & $(0.31)$ \\
\hline Number of preparedness measures taken & $0-9$ & 2.29 & $(1.75)$ & $0-9$ & 0.46 & $(0.46)$ \\
\hline \multicolumn{7}{|l|}{ Explanatory variables } \\
\hline Years of education & $0-18$ & 9.64 & $(2.79)$ & $0-18$ & 7.30 & $(4.06)$ \\
\hline Disaster experience & $0 / 1$ & 0.23 & $(0.42)$ & $0 / 1$ & 0.68 & $(0.47)$ \\
\hline Age group $<30$ & $0 / 1$ & 0.09 & $(0.28)$ & $0 / 1$ & 0.11 & $(0.31)$ \\
\hline Age group 30-39 & $0 / 1$ & 0.27 & $(0.44)$ & $0 / 1$ & 0.18 & $(0.39)$ \\
\hline Age group 40-49 & $0 / 1$ & 0.34 & $(0.47)$ & $0 / 1$ & 0.23 & $(0.42)$ \\
\hline Age group 50-59 & $0 / 1$ & 0.25 & $(0.44)$ & $0 / 1$ & 0.24 & $(0.43)$ \\
\hline Age group $\geq 60$ & $0 / 1$ & 0.05 & $(0.22)$ & $0 / 1$ & 0.23 & $(0.42)$ \\
\hline Health status & $1-11$ & 7.71 & $(2.00)$ & $0 / 1$ & 0.60 & $(0.49)$ \\
\hline Married/Cohabiting & $0 / 1$ & 0.67 & $(0.47)$ & $0 / 1$ & 0.74 & $(0.44)$ \\
\hline Currently working & $0 / 1$ & 0.90 & $(0.30)$ & $0 / 1$ & 0.81 & $(0.39)$ \\
\hline Female & - & - & - & $0 / 1$ & 0.53 & $(0.50)$ \\
\hline Mother has secondary education & $0 / 1$ & 0.25 & $(0.43)$ & - & - & - \\
\hline Father has secondary education & $0 / 1$ & 0.22 & $(0.41)$ & - & - & - \\
\hline Started working at age $\leq 12$ & $0 / 1$ & 0.12 & $(0.33)$ & - & - & - \\
\hline Household size & $1-13$ & 5.26 & $(2.04)$ & $1-14$ & 3.85 & $(1.84)$ \\
\hline$\%$ children $($ aged $\leq 5)$ in household & $0-1$ & 35.71 & $(22.49)$ & $0-1$ & 2.84 & $(9.96)$ \\
\hline$\%$ older people (aged $\geq 65$ ) in household & $0-1$ & 1.65 & $(7.04)$ & $0-1$ & 3.36 & $(14.48)$ \\
\hline$\%$ with secondary education in hh & $0-1$ & 35.51 & $(22.86)$ & $0-1$ & 20.39 & $(29.96)$ \\
\hline Years of residence & $0-75$ & 18.31 & $(10.90)$ & $0-81$ & 25.01 & $(18.07)$ \\
\hline Own house & - & - & - & $0 / 1$ & 0.88 & $(0.32)$ \\
\hline Own land & - & - & - & $0 / 1$ & 0.60 & $(0.49)$ \\
\hline House located near coast (<1km) & $0 / 1$ & 0.45 & $(0.50)$ & $0 / 1$ & 0.09 & $(0.29)$ \\
\hline House located near river $(<200 \mathrm{~m})$ & $0 / 1$ & 0.1 & $(0.29)$ & $0 / 1$ & 0.23 & $(0.42)$ \\
\hline House located near mountain $(<200 \mathrm{~m})$ & $0 / 1$ & 0.45 & $(0.50)$ & $0 / 1$ & 0.08 & $(0.27)$ \\
\hline Area 1 (PH: Batasan, TH: Phang Nga) & $0 / 1$ & 0.30 & $(0.46)$ & $0 / 1$ & 0.36 & $(0.48)$ \\
\hline Area 2 (PH: Montalban, TH: Ayutthaya) & $0 / 1$ & 0.37 & $(0.48)$ & $0 / 1$ & 0.33 & $(0.47)$ \\
\hline Area 3 (PH: Masinag, TH: Kalasin) & $0 / 1$ & 0.34 & $(0.47)$ & $0 / 1$ & 0.31 & $(0.46)$ \\
\hline \multicolumn{7}{|l|}{ Mediating factors } \\
\hline Income & $0-15300$ & 1234.6 & $(1279.3)$ & $0-250000$ & 11821.8 & $(15000)$ \\
\hline Cognitive & $0-10$ & 4.12 & $(1.46)$ & $0 / 10$ & 0.38 & $(0.48)$ \\
\hline Social capital & $0 / 1$ & 7.79 & $(2.49)$ & $0 / 1$ & 0.17 & $(0.38)$ \\
\hline Future orientation & $0-10$ & 5.33 & $(3.30)$ & - & - & - \\
\hline Risk attitude & $0-10$ & 0.77 & $(0.42)$ & - & - & - \\
\hline Low risk of disaster in community & - & - & - & $0 / 1$ & 0.14 & $(0.36)$ \\
\hline Moderate risk of disaster in community & - & - & - & $0 / 1$ & 0.33 & $(0.47)$ \\
\hline High risk of disaster in community & - & - & - & $0 / 1$ & 0.33 & $(0.47)$ \\
\hline Felt impact of climate change on family & - & - & - & $0 / 1$ & 0.57 & $(0.50)$ \\
\hline
\end{tabular}




\subsection{Estimation Strategy}

Two different outcome measures: 1) being prepared (binary); and 2) number of preparedness measures undertaken (ordinal) are used in the statistical analysis. The probability of taking preparedness action (binary outcome) is estimated using logit models while the ordinal outcome is estimated using ordered logit estimation. All standard errors are clustered at the neighbourhood $(\mathrm{PH}, \mathrm{m}=72)$ and village level $(\mathrm{TH}, \mathrm{m}=35)$. We check for the robustness of our results using different functional specification (poisson and tobit for the non-categorized, continuous outcome) and estimation procedures (multilevel modelling). All reported results are robust to the use of different procedures, ensuring the reliability of our findings.

For the empirical analysis, first, we estimate a baseline model with education $E$, disaster experience $X$, and a set of control variables $C$ on the right-hand side of the equation to test for the effects of education and experience on disaster preparedness. The baseline is then gradually extended by including a set of mediating variables $Z$ that have been identified as potentially relevant to disaster preparedness in the literature. Each mediating variable is expected to: 1) have an effect on preparedness levels; and 2) explain part of the education effects. In general form, the baseline and extended models can be written as follows:

$$
\begin{aligned}
& Y=f(E, X, C) \\
& Y=f(E, X, Z, C)
\end{aligned}
$$

The estimation procedure in the first step allows us to: 1) investigate the association between education and disaster preparedness; and 2) test whether and to what degree the relationship between education and disaster preparedness are explained by the mediating factors Z.

Following the principles of path analysis, the effect of education on disaster preparedness is decomposed into two parts: 1) indirect effect (the part mediated by Z); and 2) direct effect (the part unmediated by Z). Unlike in linear models, decomposing direct and indirect education effects, which are mediated through another factor, is not straightforward in models with a non-linear functional form such as logit or ordered logit. In these models, gradual inclusion of additional mediating factors leads to rescaling due to variation in the included variables. This makes a direct comparison of the effects between the baseline and extended model as in linear estimation impossible. Here we employ the KHB method developed by Karlson, Holm and Breen (Karlson et al. 2012) which offers a way to handle rescaling problems and to consistently compare coefficients of non-linear nested models.

The KHB method follows a two-step procedure. First, the mediating factor $Z$ is regressed on the original explanatory variable $E$, i.e. years of education in our case. From this estimation the residual $R$ is derived. $R$ captures the share in variation in the mediator that is not related to the explanatory variable, but caused by another factor. In the second step, the residual is included in the reduced baseline model in which the outcome is regressed on the explanatory 
variable not controlling for the mediator. The inclusion of the residual does not change the coefficient of the explanatory variable as $R$ is, by construction, unrelated to $E$ (only marginal changes may occur). However, by including $R$ in the model, we capture both the variation in $Z$ that is explained by $E$ (contained in the coefficient of $E$ ) and the variation unexplained by $E$ (contained in the coefficient of $R$ ). The underlying functional scale of the model, which would have changed if we simply extend the reduced model by $Z$, is harmonised between the reduced and extended model making a direct comparison of the effects possible. The KHB method further tests if the occurring difference in effect sizes between reduced and extended model is significantly different from zero i.e. if the mediating factor significantly explains part of the education effects.

\section{Results}

\subsection{Descriptive Results}

Figure 3 displays the distribution of preparedness actions taken by type of measure and country. These elicit important differences between the two countries. Overall, disaster preparedness is higher in the Philippine sample: $76.6 \%$ reported undertaking disaster preparedness actions as compared to only $34.0 \%$ in Thailand. Similar to overall disaster preparedness, the Philippines sample shows a higher degree of activities carried out for most preparedness measures, except for setting up of a family evacuation plan. For example, more than $50 \%$ of the Philippines sample reported having stockpiling food at home in order to be self-reliant in case a disaster strikes as compared to only $14.4 \%$ in Thailand. It is noticeable that while food storage, emergency kit preparation, structural upgrades and setting of a family emergency plan are common in both countries, very few respondents, $6.3 \%$ in the Philippines and $1.4 \%$ in Thailand, reported to have a disaster insurance.

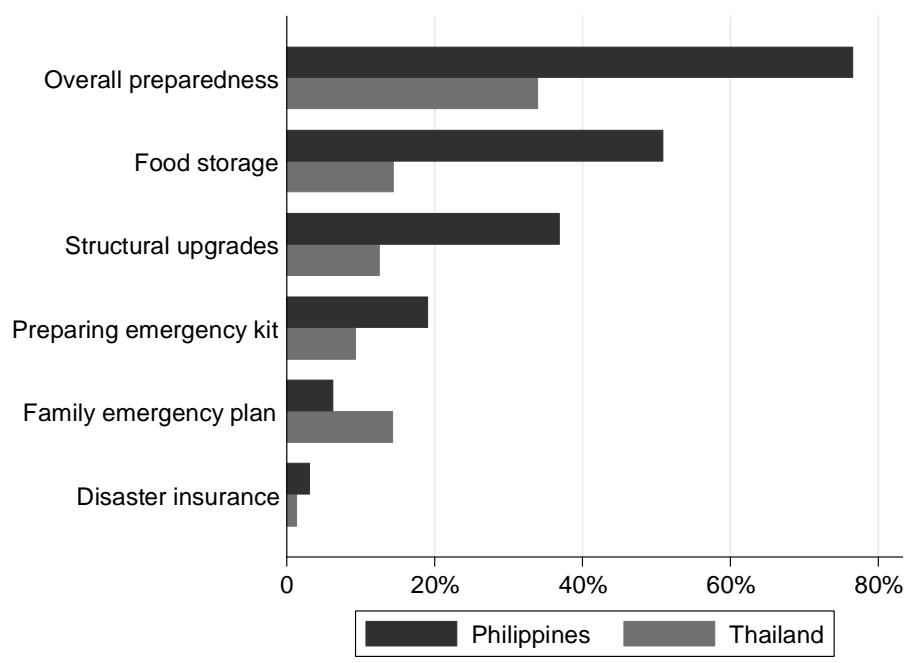

Figure 3: Disaster preparedness measures by country 


\subsection{Results from Baseline Models}

We first report the results of the baseline specification for both countries. The first two models (logit and ordered logit) in Table 2 are based on data from the Philippines while the latter two are from Thailand. Coefficients are presented in odds ratios.

Table 2: Baseline specification: logit and ordered logit models of disaster preparedness

\begin{tabular}{|c|c|c|c|c|c|c|c|c|}
\hline \multirow[b]{3}{*}{ Years of education } & \multicolumn{4}{|c|}{ Philippines } & \multicolumn{4}{|c|}{ Thailand } \\
\hline & \multicolumn{2}{|c|}{ Preparedness } & \multicolumn{2}{|c|}{ No. of measures } & \multicolumn{2}{|c|}{ Preparedness } & \multicolumn{2}{|c|}{ No. of measures } \\
\hline & $1.063+$ & {$[0.034]$} & $1.054 *$ & {$[0.027]$} & $1.041+$ & {$[0.025]$} & $1.046^{*}$ & {$[0.023]$} \\
\hline Disaster experience & $2.838 * * *$ & {$[0.759]$} & $1.880 * * *$ & {$[0.330]$} & $2.664 * *$ & {$[0.844]$} & $2.458 * *$ & {$[0.752]$} \\
\hline Age group 30-39 & 0.687 & {$[0.244]$} & 0.906 & [0.249] & $1.628 *$ & {$[0.344]$} & 1.388 & [0.329] \\
\hline Age group 40-49 & 0.917 & [0.319] & 1.035 & {$[0.250]$} & 1.344 & [0.324] & 1.230 & {$[0.260]$} \\
\hline Age group 50-59 & 0.854 & {$[0.325]$} & 0.774 & {$[0.210]$} & 0.927 & {$[0.244]$} & 0.870 & {$[0.202]$} \\
\hline Age group $\geq 60$ & 0.615 & {$[0.310]$} & 0.54 & {$[0.203]$} & 1.148 & {$[0.281]$} & 1.063 & [0.239] \\
\hline Health status & 1.048 & {$[0.037]$} & $1.064 *$ & {$[0.032]$} & 1.086 & [0.199] & 1.109 & [0.198] \\
\hline Married/Cohabiting & 1.094 & [0.181] & 1.068 & {$[0.110]$} & 1.220 & {$[0.270]$} & 1.251 & [0.264] \\
\hline Currently working & 0.993 & [0.292] & 1.156 & {$[0.240]$} & 0.784 & {$[0.170]$} & 0.864 & [0.164] \\
\hline Female & - & - & - & - & 1.284 & {$[0.200]$} & $1.308^{*}$ & [0.162] \\
\hline Mother has secondary education & 1.086 & [0.293] & 0.948 & {$[0.178]$} & - & - & - & - \\
\hline Father has secondary education & 1.166 & {$[0.244]$} & $1.440 *$ & {$[0.251]$} & - & - & - & - \\
\hline Started working at age $\leq 12$ & $0.573^{*}$ & {$[0.138]$} & 0.705 & {$[0.164]$} & - & - & - & - \\
\hline Household size & $0.879 * *$ & {$[0.041]$} & $0.921 *$ & {$[0.034]$} & 0.945 & [0.043] & 0.945 & [0.044] \\
\hline$\%$ children $($ aged $\leq 5)$ in $\mathrm{hh}$ & $1.017 * *$ & {$[0.006]$} & $1.007+$ & {$[0.004]$} & 0.999 & {$[0.006]$} & 0.999 & {$[0.005]$} \\
\hline$\%$ older people (aged $\geq 65$ ) in hh & 0.998 & {$[0.011]$} & 0.995 & {$[0.010]$} & 1.000 & {$[0.006]$} & 0.998 & {$[0.005]$} \\
\hline$\%$ with secondary education in hh & 1.008 & [0.005] & 1.004 & {$[0.004]$} & 0.999 & [0.002] & 0.999 & [0.002] \\
\hline Years of residence & $1.024 *$ & {$[0.011]$} & 1.008 & {$[0.008]$} & 0.994 & {$[0.005]$} & 0.996 & {$[0.005]$} \\
\hline Own house & - & - & - & - & 1.142 & [0.319] & 1.173 & {$[0.330]$} \\
\hline Own land & - & - & - & - & 1.301 & {$[0.267]$} & 1.213 & [0.226] \\
\hline House located near coast & - & - & - & - & $4.133 * * *$ & {$[1.768]$} & $2.532 * *$ & [0.759] \\
\hline House located near river & 0.965 & [0.219] & 0.933 & [0.195] & 0.988 & {$[0.215]$} & 1.015 & {$[0.200]$} \\
\hline House located near mountain & $0.692+$ & {$[0.147]$} & 0.862 & {$[0.155]$} & 1.347 & {$[0.686]$} & 1.526 & [0.821] \\
\hline Area 2 & $1.779^{*}$ & {$[0.507]$} & $2.041 * *$ & {$[0.469]$} & $0.390 *$ & [0.179] & $0.404 *$ & [0.178] \\
\hline Area 3 & 1.320 & [0.321] & 1.340 & [0.262] & 0.965 & {$[0.373]$} & 1.026 & [0.389] \\
\hline $\begin{array}{l}\text { Observations } \\
\text { Pseudo } \mathrm{R}^{2} \\
\text { AIC } \\
\end{array}$ & $\begin{array}{r}8 \\
0.0 \\
94 \\
\end{array}$ & & $\begin{array}{r}87 \\
0.0 \\
260 \\
\end{array}$ & & $\begin{array}{r}11 \\
0.1 \\
132 \\
\end{array}$ & $\begin{array}{l}52 \\
12 \\
6.2 \\
\end{array}$ & $\begin{array}{r}11 \\
0.0 \\
236 \\
\end{array}$ & $\begin{array}{l}52 \\
58 \\
1.5 \\
\end{array}$ \\
\hline
\end{tabular}

$+\mathrm{p}<0.1,{ }^{*} \mathrm{p}<0.05, * * \mathrm{p}<0.01, * * * \mathrm{p}<0.001$.

Notes: Cell entries are odds ratios with robust standard errors in parentheses. Standard errors are clustered at the neighbourhood level $(\mathrm{PH})$ or village level $(\mathrm{TH})$. Dummy variables of whether mother and/or father are unknown (PH) are not displayed. 
In line with previous studies, we find that education and disaster experience positively influence the propensity to undertake precautionary measures in both countries and for both outcome measures. According to the logit models, an additional year of schooling raises the odds of undertaking precautionary measures by $6.3 \%$ in the Philippines $(p<0.1)$ and by $4.1 \%$ in Thailand $(\mathrm{p}<0.1)$. This means that the probability of carrying out preparedness actions increases by $1.0 \%$ and $0.76 \%$ (evaluated at the mean), respectively, with an additional year of schooling. Similarly, disaster experience exhibits a strongly significant effect on disaster preparedness in all estimations. Based on the logit models, having been affected by a disaster in the past 3 years raises the odds of being prepared by 2.8 and 2.7 times in the Philippines and Thailand, respectively. These results are mirrored in the ordered logit regressions. In these models, the odds of falling into the group undertaking most preparedness measures versus those who undertake less measures increases by 1.88 and 2.46 times if a person experienced a disaster in the recent past in the Philippines and Thailand, respectively.

Apart from education and disaster experience as main explanatory variables, other factors also influence the preparedness level. In the Philippines, households with greater share of children are more likely to undertake preparedness measures. An increase of $10 \%$ in the proportion of household members aged $\leq 5$ leads to an increase in the odds of preparedness by $17 \%$ in the logit and $7 \%$ in the ordered logit model. Given their relatively high physical and emotional dependencies, young children are particularly vulnerable to disaster and their presence raises household's urgency for disaster preparedness accordingly. Households with a larger number of household members, on the other hand, have a smaller probability of taking preparedness actions, which might reflect wealth or social background effects. Furthermore, based on the ordered logit estimation, we find weak evidence in the Philippines that father's education level has a positive effect on respondent's tendency to prepare which might be an indication for an intergenerational transmission of educational effects. Further, respondents who started working at an early age as a proxy for family wealth in childhood, those with poor health and those who have only recently moved to a neighbourhood express a lower level of disaster preparedness. The first effect is only statistically significant in the ordered logit models while the latter two effects are only significant in the logit model. Finally, we find evidence for differences across geographical locations. The respondents from Montalban, the peri-urban area at the outskirts of Metro Manila, are significantly more likely to undertake preparedness measures than the respondents from Batasan, a neighbourhood which is only rarely affected by natural disasters. Furthermore, in the logit models, the respondents who live close to a mountain are less likely to be prepared which might reflect a lower exposure to floods and storms.

In Thailand, among the control variables, the geographical location seems to matter most. Living close range to the shoreline $(<1 \mathrm{~km})$ is positively related with disaster preparedness. At the same time, the respondents from Kalasin, one of the internal regions, express a significantly lower degree of preparedness as compared to the respondents from Phang Nga, the region most strongly affected by the 2004 Tsunami. Besides, there is weak evidence in Thailand for a gender effect in the ordered logistic regressions, with women being more likely to carry out higher number of preparedness measures as compared to men. 


\subsection{Decomposing Education Effects}

Both in the Philippines and Thailand, education has been shown to positively influence whether people undertake preparedness actions and to what extent they do it. In this section, we empirically test for different direct and indirect underlying mechanisms that might explain the observed education effects. First, the effects of potentially relevant mediating factors on disaster preparedness are estimated using the standard logit and ordered logit specification. In a second step, we consider changes in education effects between the reduced baseline and extended models to determine the explanatory power of the mediators. To identify the importance of mediating channels, the KHB method for non-linear nested models is employed.

In Table 3, the baseline model is gradually extended by various potentially relevant mediators: household income, cognitive ability, risk attitude, future orientation and social capital in the Philippines; and household income, cognitive ability, risk perception, felt impact of climate change and social capital in Thailand. For brevity, only the findings from the ordered logit estimation in Table 3 are reported. The estimates for the control variables are not included and the full models are presented in the Appendix (Tables A1 and A2). The logit model results, which widely confirm the ordered logit findings, are available upon request.

Household income per capita and cognitive ability are included in the models as first potential mediating factors. Both for the Philippines and Thai data, neither income nor cognitive ability exhibits a significant positive effect on disaster preparedness. Furthermore, future orientation, included in model 3 for the Philippines does not show a significant effect on disaster preparedness either.

In the subsequent models, variables that measure concepts related to risk attitudes and perception are considered. While risk attitudes in the Philippines do not explain differences in preparedness behaviour, we find a strongly significant positive effect of risk perception in Thailand. Compared to the reference group who perceives disaster risks to be very low, the respondents who perceive a moderate or high disaster risk are 2.41 and 2.62 times more likely to undertake preparedness measures, respectively. Similarly, perceiving that climate change has substantial impact on the family increases the odds of being in the group undertaking most preparedness measures by $81 \%$.

Next, variables that capture dimensions of social capital (measured as social support in the Philippines and social participation in Thailand) are included. Having higher social capital leads to a significant $86.5 \%$ and $107.8 \%$ increase in the odds of taking preparedness actions in the Philippines, and Thailand, respectively. Indeed, besides the perception of disaster risks, social capital is a strong determinant of disaster preparedness in both countries. 
Table 3: Extended ordered logit models: Exploring the impacts of mediators on disaster preparedness

\begin{tabular}{|c|c|c|c|c|c|c|c|}
\hline & 1 & 2 & 3 & 4 & 5 & 6 & 7 \\
\hline \multicolumn{8}{|l|}{ Philippines } \\
\hline Years of education & $\begin{array}{c}1.054 * \\
{[0.027]}\end{array}$ & $\begin{array}{c}1.053 * \\
{[0.027]}\end{array}$ & $\begin{array}{c}1.053 * \\
{[0.027]}\end{array}$ & $\begin{array}{c}1.053^{*} \\
{[0.027]}\end{array}$ & $\begin{array}{c}1.055^{*} \\
{[0.027]}\end{array}$ & $\begin{array}{c}1.058 * \\
{[0.027]}\end{array}$ & $\begin{array}{c}1.055^{*} \\
{[0.027]}\end{array}$ \\
\hline Disaster experience & $\begin{array}{c}1.880 * * * \\
{[0.330]}\end{array}$ & $\begin{array}{c}1.881 * * * \\
{[0.329]}\end{array}$ & $\begin{array}{c}1.879 * * * \\
{[0.329]}\end{array}$ & $\begin{array}{c}1.898 * * * \\
{[0.336]}\end{array}$ & $\begin{array}{c}1.869 * * * \\
{[0.327]}\end{array}$ & $\begin{array}{c}1.912 * * * \\
{[0.328]}\end{array}$ & $\begin{array}{c}1.921 * * * \\
{[0.328]}\end{array}$ \\
\hline Income & & $\begin{array}{c}1.000 \\
{[0.001]}\end{array}$ & & & & & $\begin{array}{c}1.000 \\
{[0.001]}\end{array}$ \\
\hline Cognitive & & & $\begin{array}{c}1.066 \\
{[0.052]}\end{array}$ & & & & $\begin{array}{c}1.053 \\
{[0.051]}\end{array}$ \\
\hline Future orientation & & & & $\begin{array}{c}0.979 \\
{[0.026]}\end{array}$ & & & $\begin{array}{c}0.981 \\
{[0.027]}\end{array}$ \\
\hline Risk attitude & & & & & $\begin{array}{c}1.017 \\
{[0.019]}\end{array}$ & & $\begin{array}{c}1.013 \\
{[0.018]}\end{array}$ \\
\hline Social capital & & & & & & $\begin{array}{c}1.865 * * * \\
{[0.290]}\end{array}$ & $\begin{array}{c}1.862 * * * \\
{[0.292]}\end{array}$ \\
\hline $\mathrm{N}$ & 872 & 872 & 872 & 872 & 872 & 872 & 872 \\
\hline Pseudo $\mathrm{R}^{2}$ & 0.033 & 0.034 & 0.034 & 0.034 & 0.034 & 0.04 & 0.042 \\
\hline AIC & 2606.6 & 2607.6 & 2606.6 & 2607.9 & 2607.8 & 2590.8 & 2594.6 \\
\hline \multicolumn{8}{|l|}{ Thailand } \\
\hline Years of education & $\begin{array}{c}1.046^{*} \\
{[0.023]}\end{array}$ & $\begin{array}{c}1.052 * \\
{[0.021]}\end{array}$ & $\begin{array}{c}1.047+ \\
{[0.025]}\end{array}$ & $\begin{array}{c}1.043 * \\
{[0.022]}\end{array}$ & $\begin{array}{c}1.042+ \\
{[0.022]}\end{array}$ & $\begin{array}{c}1.037+ \\
{[0.021]}\end{array}$ & $\begin{array}{c}1.039^{*} \\
{[0.018]}\end{array}$ \\
\hline Disaster experience & $\begin{array}{c}2.458 * * \\
{[0.752]}\end{array}$ & $\begin{array}{c}2.470 * * \\
{[0.755]}\end{array}$ & $\begin{array}{c}2.464 * * \\
{[0.756]}\end{array}$ & $\begin{array}{c}2.257 * * \\
{[0.685]}\end{array}$ & $\begin{array}{c}2.249 * * \\
{[0.675]}\end{array}$ & $\begin{array}{c}2.335 * * \\
{[0.692]}\end{array}$ & $\begin{array}{l}2.041 * \\
{[0.598]}\end{array}$ \\
\hline Income & & $\begin{array}{c}0.994 \\
{[0.006]}\end{array}$ & & & & & $\begin{array}{c}0.995 \\
{[0.006]}\end{array}$ \\
\hline Cognitive & & & $\begin{array}{c}0.954 \\
{[0.156]}\end{array}$ & & & & $\begin{array}{c}0.898 \\
{[0.144]}\end{array}$ \\
\hline Moderate risk of disaster & & & & $\begin{array}{c}2.411 * * * \\
{[0.638]}\end{array}$ & & & $\begin{array}{c}2.298 * * \\
{[0.637]}\end{array}$ \\
\hline High risk of disaster & & & & $\begin{array}{c}2.622 * * * \\
{[0.755]}\end{array}$ & & & $\begin{array}{c}2.407 * * \\
{[0.711]}\end{array}$ \\
\hline Felt climate change impact & & & & & $\begin{array}{c}1.806 * * \\
{[0.343]}\end{array}$ & & $\begin{array}{c}1.657 * * \\
{[0.318]}\end{array}$ \\
\hline Social capital & & & & & & $\begin{array}{c}2.078 * * * \\
{[0.357]}\end{array}$ & $\begin{array}{c}2.037 * * * \\
{[0.346]}\end{array}$ \\
\hline $\mathrm{N}$ & 1152 & 1152 & 1152 & 1152 & 1152 & 1152 & 1152 \\
\hline Pseudo $\mathrm{R}^{2}$ & 0.058 & 0.059 & 0.058 & 0.066 & 0.066 & 0.066 & 0.079 \\
\hline AIC & 2361.5 & 2362.5 & 2363.4 & 2346.4 & 2345.5 & 2344.2 & 2317.5 \\
\hline
\end{tabular}

$+\mathrm{p}<0.1, * \mathrm{p}<0.05, * * \mathrm{p}<0.01, * * * \mathrm{p}<0.001$.

Notes: Cell entries are odds ratios with robust standard errors in parentheses. Standard errors are clustered at the neighbourhood level (PH) or village level (TH). All control variables included in the models, but not displayed. 
In a final step, a full set of mediating variables is controlled for. The reported effects of all mediators remain robust in the full models. Across all models, education coefficients remain significant although for the Thai data, the size of education coefficients decreases when some of the mediators are included. In the Philippines, on the other hand, the education effects remain relatively stable. The differences in the effect sizes form the basis of the KHB analysis, which is presented in Table 4.

Table 4: KHB models: Decomposing education effects on disaster preparedness (based on ordinal outcome: number of preparedness measures taken)

\begin{tabular}{|c|c|c|c|c|c|}
\hline & Income & Cognitive & Risk attitude & $\begin{array}{c}\text { Future orien- } \\
\text { tation }\end{array}$ & $\begin{array}{l}\text { Social capi- } \\
\text { tal }\end{array}$ \\
\hline \multicolumn{6}{|l|}{ Philippines } \\
\hline \multirow[t]{2}{*}{ Total effect } & $1.054^{*}$ & $1.055^{*}$ & $1.054 *$ & $1.054 *$ & $1.052 *$ \\
\hline & [0.027] & [0.026] & [0.027] & {$[0.027]$} & [0.027] \\
\hline \multirow[t]{2}{*}{ Direct effect } & $1.053 *$ & $1.053 *$ & $1.053 *$ & $1.055^{*}$ & $1.058 *$ \\
\hline & {$[0.027]$} & {$[0.027]$} & {$[0.027]$} & {$[0.027]$} & {$[0.027]$} \\
\hline \multirow[t]{2}{*}{ Indirect effect } & 1.001 & 1.002 & 1.001 & 0.999 & 0.995 \\
\hline & {$[0.001]$} & {$[0.002]$} & {$[0.001]$} & {$[0.001]$} & {$[0.004]$} \\
\hline \multirow{3}{*}{$\begin{array}{l}\text { Effect change in \% } \\
\mathrm{N}\end{array}$} & $1.86 \%$ & $3.21 \%$ & $1.58 \%$ & $-1.30 \%$ & $-9.89 \%$ \\
\hline & 872 & 872 & 872 & 872 & 872 \\
\hline & Income & Cognitive & $\begin{array}{l}\text { Disaster risk } \\
\text { perception }\end{array}$ & $\begin{array}{l}\text { Felt climate } \\
\text { change im- } \\
\text { pact }\end{array}$ & $\begin{array}{l}\text { Social capi- } \\
\quad \text { tal }\end{array}$ \\
\hline \multirow{2}{*}{$\begin{array}{l}\text { Thailand } \\
\text { Total effect }\end{array}$} & $1.046^{*}$ & $1046 *$ & $1048 *$ & $1047 *$ & $1048 *$ \\
\hline & {$[0.023]$} & {$[0.023]$} & {$[0.023]$} & {$[0.023]$} & {$[0.023]$} \\
\hline \multirow[t]{2}{*}{ Direct effect } & $1.052 *$ & $1.047+$ & $1.043 *$ & $1.042+$ & $1.037+$ \\
\hline & {$[0.021]$} & {$[0.025]$} & {$[0.022]$} & {$[0.022]$} & {$[0.021]$} \\
\hline \multirow[t]{2}{*}{ Indirect effect } & 0.994 & 0.999 & $1.005+$ & $1.005+$ & $1.011 * *$ \\
\hline & {$[0.006]$} & {$[0.004]$} & {$[0.003]$} & {$[0.003]$} & {$[0.004]$} \\
\hline Effect change in $\%$ & $-13.65 \%$ & $-2.43 \%$ & $11.13 \%$ & $10.96 \%$ & $23.28 \%$ \\
\hline $\mathrm{N}$ & 1152 & 1152 & 1152 & 1152 & 1152 \\
\hline
\end{tabular}

$+\mathrm{p}<0.1,{ }^{*} \mathrm{p}<0.05, * * \mathrm{p}<0.01, * * * \mathrm{p}<0.001$

Notes: Cell entries are odds ratios with robust standard errors in parentheses. Standard errors are clustered at the neighbourhood level $(\mathrm{PH})$ or village level $(\mathrm{TH})$. The total effect refers to the education effect in the reduced model, the direct effect refers to the effect in the extended model. The indirect effect, which is due to changes in the mediating factor, is the difference between the total and direct effects. Effect change in $\%$ reports the percentage change in the education coefficient after controlling for the relevant mediator. Each model estimates the indirect effects separately for each mediator. All control variables are included in the models, but not displayed.

Table 4 presents the results from the KHB models where the effects of education on disaster preparedness are disentangled. The first two rows reporting total effect and direct effect show the education coefficients for the reduced model without and the extended model 
with the considered mediating factor, respectively. The last row reporting the indirect effect shows the difference between the coefficient in the reduced and extended model. Note that the estimates may slightly differ between the standard ordered logit models and KHB estimation. The delta method applied in the KHB procedure tests if the change in coefficients is significantly different from zero i.e. whether the mediating factor confounds education.

In the Philippines, the inclusion of additional factors does not lead to a significant change in the education coefficients. None of the considered theoretically relevant mediators can explain the reported education effects. Although social capital does play a role for disaster preparedness, it does not seem to be driven by differences in education levels. In Thailand, on the other hand, three of our mediators explain part of the reported education effects. Based on the KHB estimates, disaster risk perception explains $11.1 \%$, perception of the impacts of climate change $11.0 \%$ and the social capital indicator $23.3 \%$ of the previously found education effects on disaster preparedness.

\subsection{Interplay between Education and Experience}

Both education and disaster experience can trigger learning processes that lead to increased preparedness levels. If this argument holds, the effects of both variables are expected to depend on each other. We test for the interplay between the two variables in a model which includes an interaction term of education (continuous) and previous disaster experience (binary). Table 5 presents the results from the logit and ordered logit models investigating the interplay between education and disaster experience. Here only the coefficients of the main variables of interest are displayed. (Full results are shown in the Appendix in table A3).

Interestingly, when the interaction term between education and experience is included in the model, both main effects of education and experience increase. The interaction term itself is negative and statistically significant revealing an important interplay between the two factors. Similar to the results in Table 2, respondents with prior disaster experience have higher levels of preparedness. For education, however, we find that the effect differs significantly by disaster experience. The significant and negative interaction term implies that education has a positive influence on disaster preparedness only for those who have not yet experienced a disaster in the past. For the group with disaster experience, on the other hand, we find that the education effect almost cancels out. The interplay between the two variables is illustrated for both countries in the plot of marginal effects in Figure 4. 
Table 5: Exploring the interplay between education and disaster experience

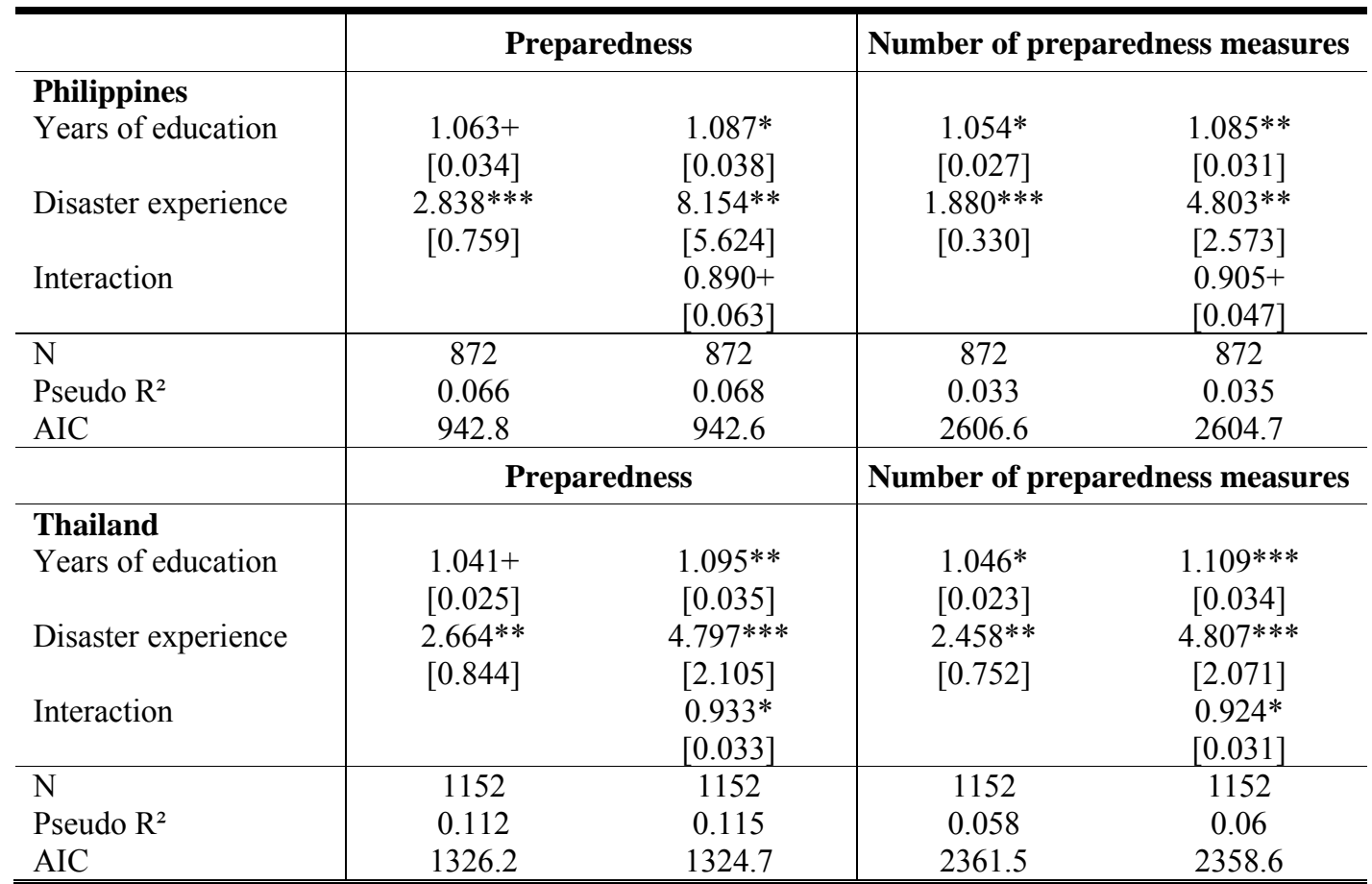

$+\mathrm{p}<0.1,{ }^{*} \mathrm{p}<0.05,{ }^{* *} \mathrm{p}<0.01,{ }^{* * *} \mathrm{p}<0.001$

Notes: Cell entries are odds ratios with robust standard errors in parentheses. Standard errors are clustered at the neighbourhood level $(\mathrm{PH})$ or village level $(\mathrm{TH})$. All control variables are included in the models, but not displayed.

Note that controlling for relevant demographic and socio-economic factors, the average preparedness level in the Philippines remains about $40 \%$ higher than in Thailand. Despite these differences in preparedness levels, we can observe the same systematic pattern with respect to the interplay between education and experience on disaster preparedness. Education significantly raises preparedness actions for those who have not been affected by a disaster in both countries. For the group with disaster experience, however, there seems to be no particular relationship between education and preparedness behaviour as depicted by a flat line in both countries.

Interestingly, education seems to allow the non-affected individuals to reach a preparedness level almost as high as their counterparts with previous disaster experience. This suggests that education does matter for disaster preparedness as long as a household has not yet encountered any disaster experience. Once being affected by a disaster, both the highly educated and less educated raise their preparedness actions to a similar level. 
Philippines: Marginal effects with 95\% Cls

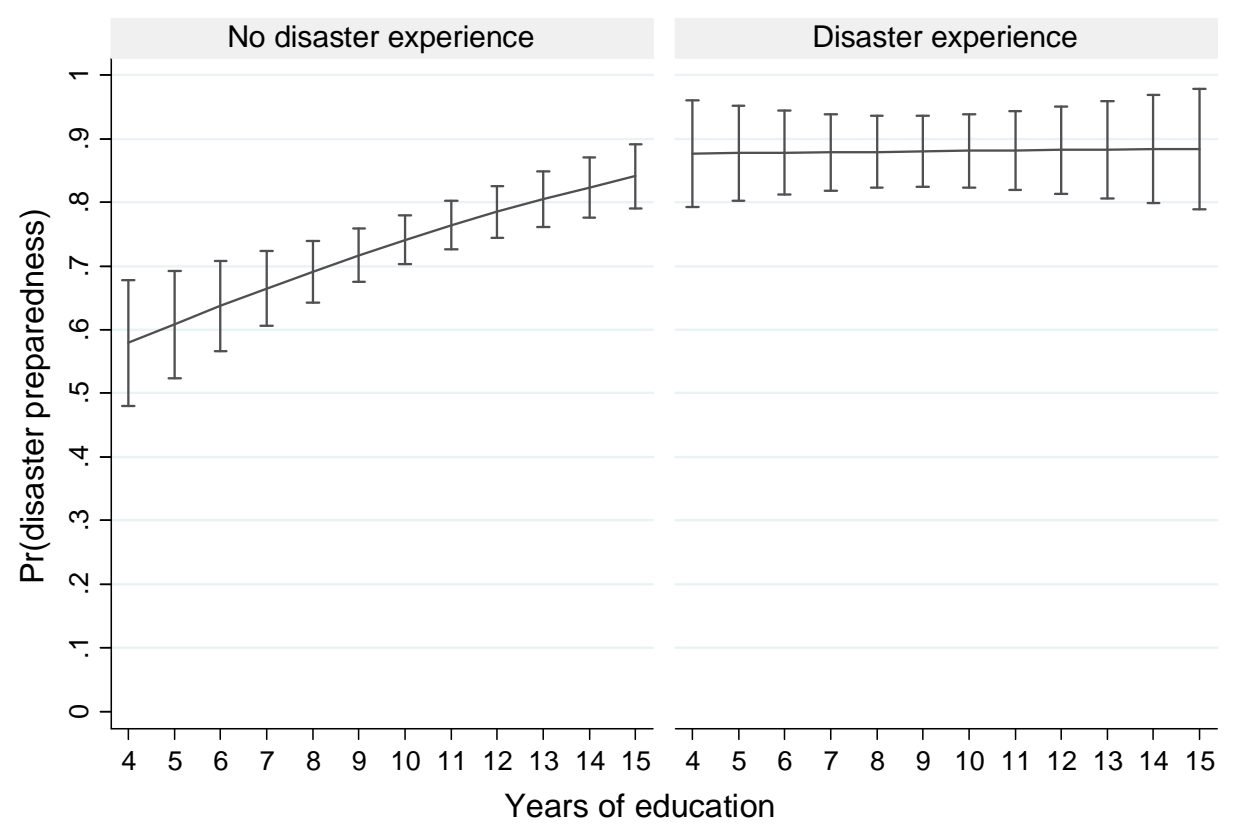

Thailand: Marginal effects with 95\% Cls

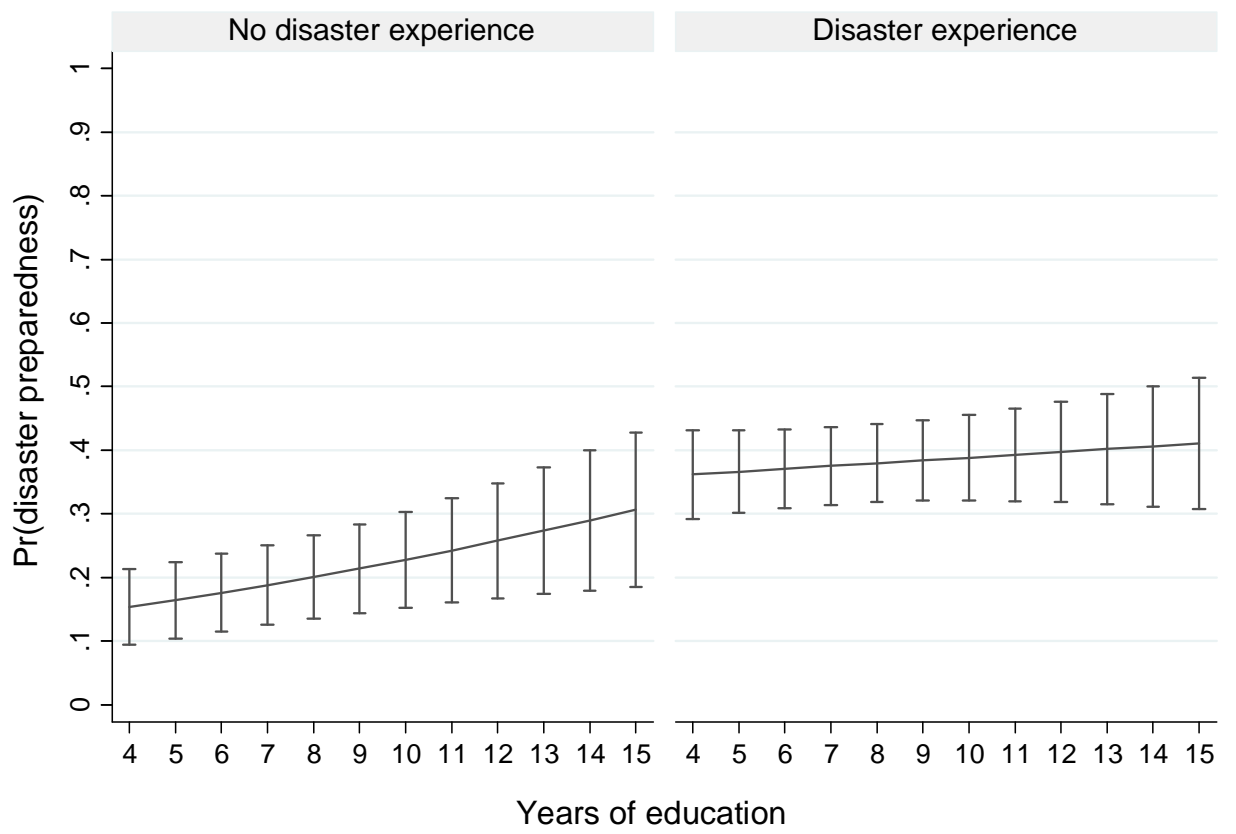

Figure 4: Plots of marginal effects from logit models displaying the probability of taking preparedness measure by years of education in the Philippines and Thailand 


\section{Discussion and Conclusion}

Analysing original survey data from the Philippines and Thailand, we have shown that education does promote preparedness behaviour particularly for people who have not been affected by a disaster in the recent past. The results are consistent for both countries and for different model specifications i.e. 1) different measurement of disaster preparedness actions; and 2) estimation strategies e.g., multilevel models. This ensures the robustness of our findings.

As expected, having experienced loss and damages from previous disaster increases disaster preparedness. In fact, prior disaster experience, which is influenced by geographical location of the home, is one of the key predictor of adoption of precautionary measures. Once being affected by a disaster, it seems that people acquired understanding of the devastation that disasters can create and hence obtained knowledge of what they can do to minimise the risk of harm (Sattler et al. 2000). In this regard, education does not seem to play a significant role since anyone who was affected by a disaster had a chance to learn about the risks of natural hazards.

Interestingly though, among those who have not previously been affected by a disaster, educational attainment becomes a key determinant of adoption of preparedness measures. Since more years of schooling is related to higher cognitive ability, logical reasoning and abstraction skills (Baker et al. 2011; Blair et al. 2005; Ceci 1991; Nisbett 2010), highly educated individuals do not need to experience a disaster to understand that disasters can be devastating. Indeed, this finding is in line with previous studies on the relationship between education and health behaviours. For instance, people with higher years of education can anticipate the harm of smoking without needing to first light up many cigarettes, become ill, and later quit smoking (de Walque 2007a). Thus, education seems to provide a protective effect against natural disaster threats.

Regarding the channels through which education influences disaster preparedness, in both the Philippines and Thailand, rather surprisingly, income does not play a particularly important role in determining preparedness behaviour. We expected that specifically in low- and middle-income countries context where government investment in disaster mitigation and risk management e.g., drainage infrastructure, land-use planning and landslide mitigation measures is relatively low (Jha \& Stanton-Geddes 2013), individuals and households have to rely on their own financial resources in implementing preparedness actions. Thus, income should be an important determinant of disaster preparedness. One explanation for this finding is possibly because most preparedness actions that our respondents in the Philippines and Thailand undertake do not require much financial investment. Among people who reported that they have taken preparedness measures, the majority store food and water in both countries and, particularly for Thailand, have a family emergency. Only $6.3 \%$ and $1.4 \%$ in the Philippines and Thailand, respectively have purchased a costly disaster insurance. Therefore in such context, income does not necessarily influence disaster preparedness.

Furthermore, we find that how education promotes disaster preparedness is contextspecific. In the Philippines, it appears that none of the possible mediating factors explain the 
effect of education on preparedness behaviour. In Thailand, we found that the highly educated have higher perceptions of disaster risks that can occur in a community as well as higher social capital which in turn increase disaster preparedness. These discrepancies between the two countries may have to do with different sampling designs of the two surveys. Not only the survey participants in the Philippines were drawn exclusively from members of a social development organization, all of them are also based in the capital, Manila. On the other hand, the Thai respondents come from a random sample of population in a selected province located in more rural settings. Indeed, it has been shown that social capital has stronger influence on life outcomes in a rural context than in an urban environment (Hofferth \& Iceland 1998). Therefore, particularly in Thailand, social capital as measured by social participation plays an important role in explaining education effects on disaster preparedness since this may provide a platform for community members to exchange information including disaster-related knowledge.

Like many other studies which rely on cross-sectional survey data, this study has three main limitations. First, this study relies on self-reported measures of preparedness actions which may be overstated by the respondents due to social desirability bias. It is possible that individuals with higher level of education over-report their preparedness behaviour in order to present themselves in a positive way following socially accepted standards. Indeed, this is found to be the case for other behaviours such as voter turnout (Karp \& Brockington 2005) or reading to children (Hofferth 1999). A different type of research design such as an observational study is required to assess patterns in reporting bias. Second, due to the cross-sectional nature of our data we are unable to make causal claims on the relationship between education, disaster experience, and preparedness actions. Longitudinal and quasi-experimental data can contribute to the identification of causal effects and to a better understanding of the underlying processes leading to disaster preparedness. Third, as mentioned above, the two surveys used in this study may not be comparable as the Philippines survey focuses on a sample of women living in an urban area while the Thai survey includes both men and women covering three provinces in different parts of Thailand. Likewise, the two countries are also exposed to different natural disaster risks which can influence both the necessity to take individual preparedness measures and the type of actions taken. Nevertheless, the main aim of this study is not to compare between the two countries but to scrutinise the effects of education on preparedness behaviour.

Although our findings on the mechanisms underlying the role of education on disaster preparedness may not be generalizable, we have empirically shown the possible pathways through which education can influence preparedness behaviour. Further investigations using better data sources (e.g., longitudinal data and nationally representative surveys) or alternative techniques (e.g., instrumental variable with educational reform as an instrument) will allow us to better identify the causal pathways between education and preventive behaviour. Likewise, more refined measurement of education including quality of schooling and curriculums will enable us to pinpoint which dimension of education matters most in promoting desirable behaviour. 
Despite the limitations, this study contributes to research on disaster risk reduction in three important ways. First, we provide new insight on the role of education in improving abstraction and generalisation-type cognitive skills. By examining the interplay between formal schooling and disaster experience, we have shown that education can substitute disaster experience in promoting taking up of precautionary measures. In other words, educated individuals can anticipate disaster risks without having to be affected by a disaster first. Second, we extend beyond current literature which have found that education can reduce vulnerability through reducing disaster mortality (Lutz et al. 2014; Striessnig et al. 2013), injury (Frankenberg et al. 2013), and asset and income loss (KC 2013), as well as improving coping capacity after a disaster (Garbero \& Muttarak 2013; Helgeson et al. 2013). Not only that our study shows that education increases preparedness actions but also identifies the underlying mechanisms through which education contribute to disaster preparedness. To our knowledge, this has not yet been done at least in the vulnerability literature. Third, not only there are relatively few studies on disaster preparedness focusing on low- and middle-income countries, comparative studies are even scarcer. This study thus provides new empirical evidence comparing disaster preparedness in two disaster-prone countries in Southeast Asia.

In this study, we have empirically shown that in the absence of disaster experience, formal education plays a key role in taking up of preparedness actions. Indeed, this is an example of positive externality of investing in human capital which extends to the aspect of vulnerability reduction. Certainly, it remains important for national government to invest in disaster risk reduction measures such as early warning systems or evacuation centres. However, it seems evident that public funding in universal education will also benefit precautionary behaviour at the personal and household level. 


\section{References}

Ablah, E., Konda, K. \& Kelley, C.L., 2009. Factors predicting individual emergency preparedness: a multi-state analysis of 2006 BRFSS data. Biosecurity and Bioterrorism, 7(3), pp.317-330.

Adiyoso, W. \& Kanegae, H., 2014. The role of Islamic teachings in encouraging people to take tsunami preparedness in Aceh and Yogyakarta Indonesia. In R. Shaw, ed. Recovery from the Indian Ocean Tsunami: A Ten-Year Journey. Tokyo: Springer Japan, pp. $259-278$.

Al-Rousan, T.M., Rubenstein, L.M. \& Wallace, R.B., 2014. Preparedness for natural disasters among older US adults: A nationwide survey. American Journal of Public Health, 104(3), pp.506-511.

Andrews, R.J. \& Quintana, L.M., 2015. Unpredictable, unpreventable and impersonal medicine: global disaster response in the 21st century. The EPMA journal, 6(1), p.2.

Baker, D.P. et al., 2011. The education effect on population health: A reassessment. Population and Development Review, 37(2), pp.307-332.

Baker, E.J., 1980. Coping with hurricane evacuation difficulties, Gainesville, Florida: Florida Sea Grant College Conference Report No. 33: Hurricane and coastal storms.

Baker, E.J., 2011. Household preparedness for the aftermath of Hurricanes in Florida. Applied Geography, 31(1), pp.46-52.

Basolo, V. et al., 2009. The effects of confidence in government and information on perceived and actual preparedness for disasters. Environment and Behavior, 41(3), pp.338-364.

Benzion, U., Rapoport, A. \& Yagil, J., 1989. Discount Rates Inferred from Decisions: An Experimental Study. Management Science, 35, pp.270-284.

Birkmann, J. et al., 2008. Extreme events and disasters: a window of opportunity for change? Analysis of organizational, institutional and political changes, formal and informal responses after mega-disasters. Natural Hazards, 55(3), pp.637-655.

Blair, C. et al., 2005. Rising mean IQ: Cognitive demand of mathematics education for young children, population exposure to formal schooling, and the neurobiology of the prefrontal cortex. Intelligence, 33(1), pp.93-106.

Boscarino, J.A. et al., 2006. Fear of terrorism and preparedness in New York City 2 years after the attacks: Implications for disaster planning and research. Journal of public health management and practice : JPHMP, 12(6), pp.505-513.

Bourque, L.B. et al., 2012. Who prepares for terrorism? Environment and Behavior, 44(3), pp.374-409.

Brower, R.S., Magno, F.A. \& Dilling, J., 2014. Evolving and Implementing a New Disaster Management Paradigm: The Case of the Philippines. In N. Kapucu \& K. T. Liou, eds. Disaster and Development. Environmental Hazards. Springer International Publishing, pp. 289-313.

De Bruin, W., Parker, A.M. \& Fischhoff, B., 2007. Individual differences in adult decisionmaking competence. Journal of Personality and Social Psychology, 92(5), pp.938-956.

Brunello, G. et al., 2015. The causal effect of education on health: What is the role of health behaviors? Health Economics, 
Bubeck, P. et al., 2013. Detailed insights into the influence of flood-coping appraisals on mitigation behaviour. Global Environmental Change, 23(5), pp.1327-1338.

Burby, R.J., Steinberg, L.J. \& Basolo, V., 2003. The tenure trap: The vulnerability of renters to joint natural and technological disasters. Urban Affairs Review, 39(1), pp.32-58.

Card, D., 1999. The causal effect of education on earnings. In O. C. A. Card \& David, eds. Handbook of Labor Economics. Elsevier, pp. 1801-1863.

Ceci, S.J., 1991. How much does schooling influence general intelligence and its cognitive components? A reassessment of the evidence. Developmental Psychology, 27(5), pp.703-722.

Chew, S.H. et al., 2010. Education and preferences: Experimental evidence from Chinese adult twins, Chicago, USA.

Cotten, S.R. \& Gupta, S.S., 2004. Characteristics of online and offline health information seekers and factors that discriminate between them. Social Science \& Medicine, 59(9), pp.1795-1806.

Cutler, D.M. \& Lleras-Muney, A., 2010. Understanding differences in health behaviors by education. Journal of Health Economics, 29(1), pp.1-28.

Dohmen, T. et al., 2011. Individual risk attitudes: Measurement, determinants, and behavioral consequences. Journal of the European Economic Association, 9, pp.522-550.

Eisenman, D.P. et al., 2009. Variations in disaster preparedness by mental health, perceived general health, and disability status. Disaster Medicine and Public Health Preparedness, 3(1), pp.33-41.

Eslinger, P.J. et al., 2009. Developmental shifts in FMRI activations during visuospatial relational reasoning. Brain and Cognition, 69(1), pp.1-10.

Faupel, C.E., Kelly, S.P. \& Petee, T., 1992. The impact of disaster education on household preparedness for Hurricane Hugo. International Journal of Mass Emergencies and Disasters, 10(1), pp.5-24.

Field, C.B. et al., 2012. Managing the risks of extreme events and disasters to advance climate change adaptation, New York: Cambridge University Press.

Frankenberg, E. et al., 2013. Education, vulnerability, and resilience after a natural disaster. Ecology and Society, 18(2).

Garbero, A. \& Muttarak, R., 2013. Impacts of the 2010 droughts and floods on community welfare in rural Thailand: Differential effects of village educational attainment. Ecology and Society, 18(4), p.27.

Gathmann, C., Jürges, H. \& Reinhold, S., 2014. Compulsory schooling reforms, education and mortality in twentieth century Europe. Social Science \& Medicine, 127, pp.74-82.

Grossman, M., 2006. Education and nonmarket outcomes, In: Hanushek, E. and Welch, F. (Ed.), Handbook of the Economics of Education, Vol. 1.

Harvatt, J., Petts, J. \& Chilvers, J., 2011. Understanding householde responses to natural hazards: Flooding and sea-level rise comparisons. Journal of Risk Research, 14(1), pp.6383.

Hausman, A.J., Hanlon, A. \& Seals, B., 2007. Social capital as a mediating factor in emergency preparedness and concerns about terrorism. Journal of Community Psychology, 35(8), pp.1073-1083. 
Helgeson, J.F., Dietz, S. \& Hochrainer-Stigler, S., 2013. Vulnerability to weather disasters: The choice of coping strategies in rural Uganda. Ecology and Society, 18(2), p.2.

Heller, K. et al., 2005. Social and personal factors as predictors of earthquake preparation: The role of support provision, network discussion, negative affect, age, and education. Journal of Applied Social Psychology, 35(2), pp.399-422.

Hofferth, S.L., 1999. Family reading to young children: Social desirability and cultural biases in reporting. In National Research Council, Committee on National Statistics.

Hofferth, S.L. \& Iceland, J., 1998. Social capital in rural and urban communities. Rural Sociology, 63(4), pp.574-598.

Horney, J. et al., 2008. Factors associated with hurricane preparedness: Results of a prehurricane assessment. Journal of Disaster Research, 3(2), pp.143-149.

Huang, J., van den Brink, H. \& Groot, W., 2009. A meta-analysis of the effect of education on social capital. Economics of Education Review, 28(4), pp.454-464.

Jackson, E.L., 1981. Response to earthquake hazard: The West Coast of North America. Environment and Behavior, 13(4), pp.387-416.

Jha, A.K. \& Stanton-Geddes, Z. eds., 2013. Strong, Safe, and Resilient: A Strategic Policy Guide for Disaster Risk Management in East Asia and the Pacific, Washington, D.C.: World Bank Publications.

Kandel, E.R., 2007. In search of memory: The emergence of a new science of mind, New York: W.W. Norton \& Co.

Karlson, K.B., Holm, A. \& Breen, R., 2012. Comparing Regression Coefficients Between Same-sample Nested Models Using Logit and Probit A New Method. Sociological Methodology, 42(1), pp.286-313.

Karp, J.A. \& Brockington, D., 2005. Social desirability and response validity: A comparative analysis of overreporting voter turnout in five countries. Journal of Politics, 67(3), pp.825-840.

KC, S., 2013. Community vulnerability to floods and landslides in Nepal. Ecology and Society, 18(1).

Kellens, W., Terpstra, T. \& De Maeyer, P., 2013. Perception and communication of flood risks: A systematic review of empirical research. Risk Analysis, 33(1), pp.24-49.

Kenkel, D.S., 1991. Health Behavior, Health Knowledge, and Schooling. Journal of Political Economy, 99(2), p.287.

Kim, Y.-C. \& Kang, J., 2010. Communication, neighbourhood belonging and household hurricane preparedness. Disasters, 34(2), pp.470-488.

Kirschenbaum, A., 2006. Families and disater behavior: A reassessment of family preparedness. International Journal of Mass Emergencies and Disasters, 24(1), pp.111-143.

Kohn, S. et al., 2012. Personal disaster preparedness: an integrative review of the literature. Disaster medicine and public health preparedness, 6(3), pp.217-231.

Lake, R.L.D. \& Huckfeldt, R., 1998. Social capital, social networks, and political participation. Political Psychology, 19(3), pp.567-584.

Lave, T.R. \& Lave, L.B., 1991. Public perception of the risks of floods: implications for communication. Risk Analysis, 11(2), pp.255-267. 
Lawrence, J., Quade, D. \& Becker, J., 2014. Integrating the effects of flood experience on risk perception with responses to changing climate risk. Natural Hazards, 74(3), pp.17731794.

Lee, J.E.C. \& Lemyre, L., 2009. A social-cognitive perspective of terrorism risk perception and individual response in Canada. Risk Analysis, 29(9), pp.1265-1280.

Lindell, M.K. \& Hwang, S.N., 2008. Households' perceived personal risk and responses in a multihazard environment. Risk Analysis, 28(2), pp.539-556.

Lindell, M.K. \& Whitney, D.J., 2000. Correlates of household seismic hazard adjustment adoption. Risk Analysis, 20(1), pp.13-26.

Lutz, W., Muttarak, R. \& Striessnig, E., 2014. Universal education is key to enhanced climate adaptation. Science, 346(6213), pp.1061-1062.

Martin, W.E., Martin, I.M. \& Kent, B., 2009. The role of risk perceptions in the risk mitigation process: The case of wildfire in high risk communities. Journal of Environmental Management, 91(2), pp.489-498.

McGee, T.K. \& Russell, S., 2003. "It's just a natural way of life..." an investigation of wildfire preparedness in rural Australia. Global Environmental Change Part B: Environmental Hazards, 5(1-2), pp.1-12.

McNeill, I.M. et al., 2013. Expecting the unexpected: Predicting physiological and psychological wildfire preparedness from perceived risk, responsibility, and obstacles. Risk Analysis, 33(10), pp.1829-1843.

Miceli, R., Sotgiu, I. \& Settanni, M., 2008. Disaster preparedness and perception of flood risk: A study in an alpine valley in Italy. Journal of Environmental Psychology, 28(2), pp.164-173.

Mileti, D.S. \& Darlington, J.D., 1995. Societal response to revised earthquake probabilities in the San Francisco bay area. International Journal of Mass Emergencies and Disasters, 13(2), pp.119-145.

Mileti, D.S., Fitzpatrick, C. \& Farhar, B.C., 1992. Fostering public preparations for natural hazards: Lessons from the Parkfield earthquake prediction. Environment: Science and Policy for Sustainable Development, 34(3), pp.16-39.

Mileti, D.S. \& O’Brien, P.W., 1992. Warnings during disaster: Normalizing communicated risk. Social Problems, 39(1), pp.40-57.

Mishra, S. \& Suar, D., 2007. Do lessons people learn determine disaster cognition and preparedness? Psychology \& Developing Societies, 19(2), pp.143-159.

Murphy, S.T. et al., 2009. Predictors of emergency preparedness and compliance. Disaster Medicine and Public Health Preparedness.

Muttarak, R. \& Pothisiri, W., 2013. The role of education on disaster preparedness: Case study of 2012 Indian Ocean earthquakes on Thailand's Andaman coast. Ecology and Society, $18(4)$, p.51.

Neuenschwander, L.M., Abbott, A. \& Mobley, A.R., 2012. Assessment of low-income adults' access to technology: Implications for nutrition education. Journal of Nutrition Education and Behavior, 44(1), pp.60-65.

Nguyen, L.H. et al., 2006. Exploring the causal relationship between exposure to the 1994 Northridge earthquake and pre- and post-earthquake preparedness activities. Earthquake Spectra, 22(3), pp.569-587. 
Nisbett, R.E., 2010. Intelligence and How to Get It: Why Schools and Cultures Count, New York: W. W. Norton \& Company.

Norris, F.H., Smith, T. \& Kaniasty, K., 1999. Revisiting the experience-behavior hypothesis: The effects of Hurricane Hugo on hazard preparedness and other self-protective acts. Basic and Applied Social Psychology, 21(1), pp.37-47.

Oberauer, K. et al., 2000. Working memory capacity - facets of a cognitive ability construct. Personality and Individual Differences, 29, pp.1017-1045.

Oreopoulos, P. \& Salvanes, K.G., 2011. Priceless: The Nonpecuniary Benefits of Schooling. Journal of Economic Perspectives, 25(1), pp.159-84.

Paton, D. \& Johnston, D., 2001. Disasters and communities: vulnerability, resilience and preparedness. Disaster Prevention and Management, 10(4), pp.270-277.

Paton, D., Millar, M. \& Johnston, D., 2001. Community resilience to volcanic hazard consequences. Natural Hazards, 24(2), pp.157-169.

Paul, B.K. \& Bhuiyan, R.H., 2010. Urban earthquake hazard: Perceived seismic risk and preparedness in Dhaka City, Bangladesh. Disasters, 34(2), pp.337-359.

Pérez-Arce, F., 2011. The effect of education on time preferences, Rochester, NY.

Peters, E. et al., 2006. Numeracy and decision making. Psychological Science, 17(5), pp.407413.

Phillips, B.D., Metz, W.C. \& Nieves, L.A., 2005. Disaster threat: Preparedness and potential response of the lowest income quartile. Environmental Hazards, 6(3), pp.123-133.

Quartz, S.R. \& Sejnowski, T.J., 1997. The neural basis of cognitive development: a constructivist manifesto. The Behavioral and Brain Sciences, 20(4), pp.537-596.

Reininger, B.M. et al., 2013. Social capital and disaster preparedness among low income Mexican Americans in a disaster prone area. Social Science \& Medicine, 83, pp.50-60.

Rincon, E., Linares, M.Y.-R. \& Greenberg, B., 2001. Effect of previous experience of a hurricane on preparedness for future hurricanes. The American Journal of Emergency Medicine, 19(4), pp.276-279.

Rodriguez, H. et al., 2007. Communicating risk and uncertainty: Science, technology, and disasters at the crossroads. In Handbook of Disaster Research. Handbooks of Sociology and Social Research. Springer New York, pp. 476-488.

Russell, L.A., Goltz, J.D. \& Bourque, L.B., 1995. Preparedness and hazard mitigation actions before and after two earthquakes. Environment and Behavior, 27(6), pp.744-770.

Sattler, D.N., Kaiser, C.F. \& Hittner, J.B., 2000. Disaster preparedness: Relationships among prior experience, personal characteristics, and distress. Journal of Applied Social Psychology, 30(7), pp.1396-1420.

Shelley, M.K., 1993. Outcome Signs, Question Frames and Discount Rates. Management Science, 39, pp.806-815.

Siegel, J.M. et al., 2003. Surviving two disasters: Does reaction to the first predict response to the second? Environment and Behavior, 35(5), pp.637-654.

Siegrist, M. \& Gutscher, H., 2008. Natural hazards and motivation for mitigation behavior: People cannot predict the affect evoked by a severe flood. Risk Analysis: An Official Publication of the Society for Risk Analysis, 28(3), pp.771-778.

Sims, J.H. \& Baumann, D.D., 1983. Educational Programs and Human Response to Natural Hazards. Environment and Behavior, 15(2), pp.165-189. 
Smith, D.L. \& Notaro, S.J., 2009. Personal emergency preparedness for people with disabilities from the 2006-2007 Behavioral Risk Factor Surveillance System. Disability and Health Journal, 2(2), pp.86-94.

Solberg, C., Rossetto, T. \& Joffe, H., 2010. The social psychology of seismic hazard adjustment: re-evaluating the international literature. Nat. Hazards Earth Syst. Sci., 10(8), pp.1663-1677.

Sorensen, J.H., 1983. Knowing how to behave under the threat of disaster can it be explained? Environment and Behavior, 15(4), pp.438-457.

Spittal, M.J. et al., 2008. Predictors of two types of earthquake preparation: Survival activities and mitigation activities. Environment and Behavior, 40(6), pp.798-817.

Striessnig, E., Lutz, W. \& Patt, A.G., 2013. Effects of Educational Attainment on Climate Risk Vulnerability. , 18(1).

Tanaka, K., 2005. The impact of disaster education on public preparation and mitigation for earthquakes: A cross-country comparison between Fukui, Japan and the San Francisco Bay Area, California, USA. Applied Geography, 25(3), pp.201-225.

Tekeli-Yeşil, S. et al., 2010. Individual preparedness and mitigation actions for a predicted earthquake in Istanbul. Disasters, 34(4), pp.910-930.

Thieken, A.H. et al., 2007. Coping with floods: preparedness, response and recovery of floodaffected residents in Germany in 2002. Hydrological Sciences Journal, 52(5), pp.10161037.

De Walque, D., 2007a. Does education affect smoking behaviors?. Evidence using the Vietnam draft as an instrument for college education. Journal of Health Economics, 26(5), pp.877-895.

De Walque, D., 2007b. How does the impact of an HIV/AIDS information campaign vary with educational attainment? Evidence from rural Uganda. Journal of Development Economics, 84(2), pp.686-714.

De Walque, D. de, 2010. Education, information, and smoking decisions evidence from smoking histories in the United States, 1940-2000. Journal of Human Resources, 45(3), pp.682-717.

Wen, L.M. et al., 2011. Who is NOT likely to access the Internet for health information? Findings from first-time mothers in southwest Sydney, Australia. International Journal of Medical Informatics, 80(6), pp.406-411.

Witvorapong, N., Muttarak, R. \& Pothisiri, W., 2015. Social Participation and Disaster Risk Reduction Behaviors in Tsunami Prone Areas. Plos One, 10(7)

Wood, M.M. et al., 2012. Communicating actionable risk for terrorism and other hazards. Risk Analysis: An Official Publication of the Society for Risk Analysis, 32(4), pp.601-615.

Xiao, C. \& McCright, A.M., 2007. Environmental concern and sociodemographic variables: A study of statistical models. The Journal of Environmental Education, 38(2), pp.3-14. 
Appendix 
Table A1: Extended ordered logit models for Philippines data (effects of controls reported)

\begin{tabular}{|c|c|c|c|c|c|c|c|}
\hline & 1 & 2 & 3 & 4 & 5 & 6 & 7 \\
\hline \multirow[t]{2}{*}{ Years of education } & $1.054 *$ & $1.053^{*}$ & $1.053^{*}$ & $1.053^{*}$ & $1.055^{*}$ & $1.058 *$ & $1.055^{*}$ \\
\hline & {$[0.027]$} & {$[0.027]$} & {$[0.027]$} & {$[0.027]$} & {$[0.027]$} & {$[0.027]$} & {$[0.027]$} \\
\hline \multirow[t]{2}{*}{ Disaster experience } & $1.880 * * *$ & $1.881 * * *$ & $1.879 * * *$ & $1.898 * * *$ & $1.869 * * *$ & $1.912 * * *$ & $1.921 * * *$ \\
\hline & {$[0.330]$} & [0.329] & [0.329] & {$[0.336]$} & {$[0.327]$} & {$[0.328]$} & {$[0.328]$} \\
\hline \multirow[t]{2}{*}{ Income } & & 1.000 & & & & & 1.000 \\
\hline & & {$[0.001]$} & & & & & {$[0.001]$} \\
\hline \multirow[t]{2}{*}{ Cognitive } & & & 1.066 & & & & 1.053 \\
\hline & & & {$[0.052]$} & & & & {$[0.051]$} \\
\hline \multirow[t]{2}{*}{ Future orientation } & & & & 0.979 & & & 0.981 \\
\hline & & & & {$[0.026]$} & & & {$[0.027]$} \\
\hline \multirow[t]{2}{*}{ Risk attitude } & & & & & 1.017 & & 1.013 \\
\hline & & & & & [0.019] & & {$[0.018]$} \\
\hline \multirow[t]{2}{*}{ Social capital } & & & & & & $1.865 * * *$ & $1.862 * * *$ \\
\hline & & & & & & {$[0.290]$} & {$[0.292]$} \\
\hline \multirow[t]{2}{*}{ Age group 30-39 } & 0.906 & 0.896 & 0.912 & 0.915 & 0.912 & 0.922 & 0.929 \\
\hline & {$[0.249]$} & [0.247] & [0.249] & {$[0.254]$} & {$[0.251]$} & {$[0.252]$} & {$[0.255]$} \\
\hline \multirow[t]{2}{*}{ Age group 40-49 } & 1.035 & 1.025 & 1.049 & 1.045 & 1.052 & 1.084 & 1.103 \\
\hline & {$[0.250]$} & {$[0.246]$} & {$[0.251]$} & {$[0.255]$} & {$[0.255]$} & [0.249] & {$[0.256]$} \\
\hline \multirow[t]{2}{*}{ Age group 50-59 } & 0.774 & 0.766 & 0.798 & 0.779 & 0.787 & 0.828 & 0.85 \\
\hline & {$[0.210]$} & [0.207] & [0.215] & {$[0.213]$} & {$[0.213]$} & {$[0.214]$} & {$[0.220]$} \\
\hline \multirow[t]{2}{*}{ Age group $\geq 60$} & 0.54 & 0.541 & 0.578 & 0.546 & 0.547 & 0.544 & 0.591 \\
\hline & {$[0.203]$} & [0.204] & {$[0.218]$} & {$[0.208]$} & {$[0.206]$} & {$[0.205]$} & {$[0.227]$} \\
\hline \multirow[t]{2}{*}{ Health status } & $1.064 *$ & $1.061+$ & $1.065 *$ & $1.066^{*}$ & $1.062 *$ & $1.072 *$ & $1.071 *$ \\
\hline & {$[0.032]$} & {$[0.032]$} & {$[0.032]$} & {$[0.031]$} & {$[0.032]$} & {$[0.032]$} & {$[0.032]$} \\
\hline \multirow[t]{2}{*}{ Married/Cohabiting } & 1.068 & 1.067 & 1.063 & 1.063 & 1.068 & 1.051 & 1.039 \\
\hline & {$[0.110]$} & {$[0.109]$} & {$[0.111]$} & {$[0.109]$} & {$[0.111]$} & {$[0.110]$} & {$[0.110]$} \\
\hline \multirow[t]{2}{*}{ Currently working } & 1.156 & 1.124 & 1.176 & 1.158 & 1.169 & 1.098 & 1.085 \\
\hline & {$[0.240]$} & [0.239] & {$[0.238]$} & {$[0.241]$} & [0.242] & {$[0.228]$} & {$[0.225]$} \\
\hline \multirow{2}{*}{ Mother has secondary education } & 0.948 & 0.946 & 0.928 & 0.942 & 0.944 & 0.902 & 0.874 \\
\hline & {$[0.178]$} & [0.179] & {$[0.172]$} & {$[0.177]$} & {$[0.177]$} & {$[0.169]$} & {$[0.163]$} \\
\hline \multirow{2}{*}{ Father has secondary education } & $1.440^{*}$ & $1.433 *$ & $1.437^{*}$ & $1.449 *$ & $1.446^{*}$ & $1.490^{*}$ & $1.496^{*}$ \\
\hline & {$[0.251]$} & {$[0.251]$} & {$[0.253]$} & {$[0.253]$} & {$[0.253]$} & {$[0.249]$} & {$[0.258]$} \\
\hline \multirow{2}{*}{ Started working at age $\leq 12$} & 0.911 & 0.917 & 0.917 & 0.91 & 0.908 & 0.959 & 0.967 \\
\hline & [0.291] & {$[0.290]$} & [0.291] & {$[0.290]$} & {$[0.286]$} & {$[0.300]$} & {$[0.295]$} \\
\hline Household size & 0.691 & 0.688 & 0.7 & 0.681 & 0.691 & 0.692 & 0.688 \\
\hline & {$[0.195]$} & {$[0.192]$} & {$[0.200]$} & {$[0.193]$} & {$[0.195]$} & {$[0.197]$} & {$[0.196]$} \\
\hline$\%$ children $($ aged $\leq 5)$ in hh & 0.705 & 0.703 & 0.703 & 0.704 & 0.706 & 0.722 & 0.719 \\
\hline & {$[0.164]$} & {$[0.164]$} & {$[0.164]$} & {$[0.165]$} & {$[0.164]$} & [0.169] & [0.169] \\
\hline$\%$ older people (aged $>65$ ) in $\mathrm{hh}$ & 0.769 & 0.781 & 0.729 & 0.769 & 0.798 & 0.861 & 0.862 \\
\hline$\%$ older people (aged $\geq$ bJ) in $\mathrm{nh}$ & {$[0.243]$} & {$[0.249]$} & {$[0.231]$} & {$[0.248]$} & {$[0.258]$} & {$[0.300]$} & {$[0.316]$} \\
\hline & $0.921 *$ & $0.926^{*}$ & $0.920 *$ & $0.921 *$ & $0.923^{*}$ & $0.923^{*}$ & $0.932+$ \\
\hline$\%$ with secondary education in hh & {$[0.034]$} & {$[0.035]$} & {$[0.034]$} & {$[0.034]$} & {$[0.034]$} & {$[0.033]$} & {$[0.036]$} \\
\hline Years of residence & 1.008 & 1.008 & 1.007 & 1.008 & 1.007 & 1.006 & 1.007 \\
\hline & {$[0.008]$} & {$[0.008]$} & {$[0.008]$} & {$[0.008]$} & {$[0.008]$} & {$[0.008]$} & {$[0.008]$} \\
\hline House located near river & 0.933 & 0.939 & 0.932 & 0.932 & 0.936 & 0.931 & 0.937 \\
\hline & {$[0.195]$} & {$[0.195]$} & {$[0.194]$} & {$[0.194]$} & {$[0.193]$} & {$[0.189]$} & {$[0.188]$} \\
\hline House located near mountain & 0.862 & 0.862 & 0.861 & 0.866 & 0.86 & 0.861 & 0.86 \\
\hline & {$[0.155]$} & {$[0.155]$} & {$[0.155]$} & {$[0.156]$} & {$[0.153]$} & [0.159] & {$[0.157]$} \\
\hline Area 2 & $2.041 * *$ & $2.059 * *$ & $2.042 * *$ & $2.018 * *$ & $2.030 * *$ & $2.139 * * *$ & $2.132 * * *$ \\
\hline & [0.469] & {$[0.472]$} & {$[0.467]$} & {$[0.468]$} & {$[0.467]$} & {$[0.476]$} & {$[0.477]$} \\
\hline Area 3 & 1.34 & 1.326 & 1.353 & 1.337 & 1.344 & 1.369 & 1.363 \\
\hline & [0.262] & {$[0.260]$} & {$[0.266]$} & {$[0.261]$} & {$[0.264]$} & [0.267] & [0.268] \\
\hline $\mathrm{N}$ & 872 & 872 & 872 & 872 & 872 & 872 & 872 \\
\hline Pseudo $\mathrm{R}^{2}$ & 0.033 & 0.034 & 0.034 & 0.034 & 0.034 & 0.04 & 0.042 \\
\hline $\mathrm{AIC}$ & 2606.6 & 2607.6 & 2606.6 & 2607.9 & 2607.8 & 2590.8 & 2594.6 \\
\hline
\end{tabular}

$+\mathrm{p}<0.1, * \mathrm{p}<0.05, * * \mathrm{p}<0.01, * * * \mathrm{p}<0.001$

Notes: Cell entries are odds ratios with robust standard errors in parentheses. Standard errors are clustered at the neighborhood level. 
Table A2 - Extended ordered logit models for Thai data (effects of controls reported)

\begin{tabular}{|c|c|c|c|c|c|c|c|}
\hline & 1 & 2 & 3 & 4 & 5 & 6 & 7 \\
\hline \multirow[t]{2}{*}{ Years of education } & $1.046^{*}$ & $1.052 *$ & $1.047+$ & $1.043 *$ & $1.042+$ & $1.037+$ & $1.039 *$ \\
\hline & {$[0.023]$} & {$[0.021]$} & {$[0.025]$} & {$[0.022]$} & {$[0.022]$} & {$[0.021]$} & {$[0.018]$} \\
\hline \multirow[t]{2}{*}{ Disaster experience } & $2.458 * *$ & $2.470 * *$ & $2.464 * *$ & $2.257 * *$ & $2.249 * *$ & $2.335 * *$ & $2.041 *$ \\
\hline & {$[0.752]$} & {$[0.755]$} & {$[0.756]$} & {$[0.685]$} & {$[0.675]$} & {$[0.692]$} & {$[0.598]$} \\
\hline \multirow[t]{2}{*}{ Income } & & 0.994 & & & & & 0.995 \\
\hline & & {$[0.006]$} & & & & & {$[0.006]$} \\
\hline \multirow[t]{2}{*}{ Cognitive } & & & 0.954 & & & & 0.898 \\
\hline & & & {$[0.156]$} & & & & {$[0.144]$} \\
\hline \multirow[t]{2}{*}{ Moderate disaster risk } & & & & $2.411 * * *$ & & & $2.298 * *$ \\
\hline & & & & {$[0.638]$} & & & {$[0.637]$} \\
\hline \multirow[t]{2}{*}{ High disaster risk } & & & & $2.622 * * *$ & & & $2.407 * *$ \\
\hline & & & & {$[0.755]$} & & & {$[0.711]$} \\
\hline \multirow[t]{2}{*}{ Felt climate change impact } & & & & & $1.806 * *$ & & $1.657 * *$ \\
\hline & & & & & {$[0.343]$} & & {$[0.318]$} \\
\hline \multirow[t]{2}{*}{ Social capital } & & & & & & $2.078 * * *$ & $2.037 * * *$ \\
\hline & & & & & & {$[0.357]$} & {$[0.346]$} \\
\hline \multirow[t]{2}{*}{ Age group 30-39 } & 1.388 & 1.375 & 1.387 & 1.406 & 1.342 & 1.369 & 1.328 \\
\hline & {$[0.329]$} & {$[0.319]$} & [0.328] & {$[0.333]$} & {$[0.308]$} & {$[0.330]$} & {$[0.306]$} \\
\hline \multirow[t]{2}{*}{ Age group 40-49 } & 1.23 & 1.206 & 1.221 & 1.27 & 1.191 & 1.133 & 1.1 \\
\hline & {$[0.260]$} & {$[0.248]$} & {$[0.267]$} & {$[0.278]$} & {$[0.251]$} & {$[0.231]$} & {$[0.231]$} \\
\hline \multirow[t]{2}{*}{ Age group 50-59 } & 0.87 & 0.869 & 0.859 & 0.893 & 0.826 & 0.754 & 0.711 \\
\hline & {$[0.202]$} & [0.199] & {$[0.204]$} & {$[0.214]$} & {$[0.191]$} & {$[0.163]$} & {$[0.161]$} \\
\hline \multirow[t]{2}{*}{ Age group $\geq 60$} & 1.063 & 1.054 & 1.047 & 1.104 & 1.003 & 1.006 & 0.937 \\
\hline & {$[0.239]$} & {$[0.237]$} & [0.249] & {$[0.260]$} & {$[0.220]$} & {$[0.245]$} & {$[0.238]$} \\
\hline \multirow[t]{2}{*}{ Health status } & 1.109 & 1.103 & 1.108 & 1.132 & 1.135 & 1.054 & 1.086 \\
\hline & [0.198] & {$[0.200]$} & [0.198] & {$[0.205]$} & {$[0.210]$} & [0.195] & {$[0.210]$} \\
\hline \multirow[t]{2}{*}{ Married/Cohabiting } & 1.251 & 1.234 & 1.248 & 1.242 & 1.205 & 1.22 & 1.156 \\
\hline & {$[0.264]$} & {$[0.264]$} & {$[0.264]$} & {$[0.248]$} & {$[0.240]$} & {$[0.258]$} & {$[0.229]$} \\
\hline \multirow[t]{2}{*}{ Currently working } & 0.864 & 0.878 & 0.865 & 0.866 & 0.816 & 0.88 & 0.852 \\
\hline & {$[0.164]$} & {$[0.167]$} & {$[0.165]$} & {$[0.168]$} & {$[0.142]$} & {$[0.166]$} & {$[0.153]$} \\
\hline Female & $1.308^{*}$ & $1.312 *$ & $1.310^{*}$ & $1.281^{*}$ & $1.314^{*}$ & $1.325^{*}$ & $1.312 *$ \\
\hline & {$[0.162]$} & {$[0.160]$} & {$[0.160]$} & [0.159] & {$[0.170]$} & {$[0.176]$} & {$[0.171]$} \\
\hline Household size & 0.945 & 0.947 & 0.945 & 0.945 & 0.949 & 0.936 & 0.943 \\
\hline & {$[0.044]$} & {$[0.043]$} & {$[0.044]$} & {$[0.043]$} & {$[0.044]$} & {$[0.043]$} & {$[0.042]$} \\
\hline$\%$ children $($ aged $\leq 5)$ in $\mathrm{hh}$ & 0.999 & 0.998 & 0.999 & 0.999 & 0.999 & 1 & 0.999 \\
\hline & {$[0.005]$} & {$[0.005]$} & {$[0.005]$} & {$[0.005]$} & {$[0.005]$} & {$[0.005]$} & {$[0.005]$} \\
\hline & 0.998 & 0.998 & 0.998 & 0.997 & 0.999 & 0.999 & 0.999 \\
\hline$\%$ older people $($ aged $\geq 65)$ in hh & {$[0.005]$} & {$[0.005]$} & {$[0.005]$} & {$[0.005]$} & {$[0.005]$} & {$[0.005]$} & {$[0.005]$} \\
\hline & 0.999 & 0.998 & 0.999 & 0.999 & 0.999 & 0.999 & 1.000 \\
\hline$\%$ with secondary education in hh & {$[0.002]$} & {$[0.002]$} & {$[0.002]$} & {$[0.002]$} & {$[0.002]$} & {$[0.002]$} & {$[0.002]$} \\
\hline Years of residence & 0.996 & 0.996 & 0.996 & 0.996 & 0.997 & 0.996 & 0.996 \\
\hline & {$[0.005]$} & {$[0.005]$} & {$[0.005]$} & {$[0.005]$} & {$[0.005]$} & {$[0.005]$} & {$[0.005]$} \\
\hline Own house & 1.173 & 1.159 & 1.174 & 1.242 & 1.241 & 1.099 & 1.218 \\
\hline & {$[0.330]$} & {$[0.325]$} & {$[0.330]$} & {$[0.352]$} & {$[0.348]$} & {$[0.308]$} & {$[0.339]$} \\
\hline Own land & 1.213 & 1.223 & 1.211 & 1.159 & 1.208 & 1.253 & 1.205 \\
\hline & {$[0.226]$} & {$[0.224]$} & {$[0.228]$} & {$[0.206]$} & {$[0.238]$} & {$[0.227]$} & {$[0.215]$} \\
\hline House located near coast & $2.532 * *$ & $2.540 * *$ & $2.529 * *$ & $2.486 * *$ & $2.680 * * *$ & $2.538 * *$ & $2.595 * *$ \\
\hline & {$[0.759]$} & {$[0.756]$} & {$[0.756]$} & {$[0.767]$} & {$[0.769]$} & {$[0.765]$} & {$[0.756]$} \\
\hline House located near river & 1.015 & 1.02 & 1.013 & 1.049 & 1.042 & 1.014 & 1.069 \\
\hline & {$[0.200]$} & {$[0.202]$} & {$[0.202]$} & {$[0.220]$} & [0.219] & {$[0.213]$} & {$[0.247]$} \\
\hline House located near mountain & 1.526 & 1.562 & 1.516 & 1.692 & 1.461 & 1.36 & 1.423 \\
\hline & {$[0.821]$} & {$[0.802]$} & [0.809] & {$[0.904]$} & {$[0.800]$} & {$[0.663]$} & {$[0.658]$} \\
\hline Area 2 & $0.404^{*}$ & $0.385^{*}$ & $0.400^{*}$ & $0.406^{*}$ & $0.352 *$ & $0.386^{*}$ & $0.326^{*}$ \\
\hline & {$[0.178]$} & {$[0.173]$} & {$[0.176]$} & {$[0.184]$} & {$[0.157]$} & {$[0.166]$} & {$[0.146]$} \\
\hline Area 3 & 1.026 & 1.014 & 1.017 & 1.071 & 0.907 & 1.051 & 0.949 \\
\hline & [0.389] & {$[0.382]$} & {$[0.390]$} & {$[0.406]$} & {$[0.314]$} & {$[0.398]$} & {$[0.335]$} \\
\hline $\mathrm{N}$ & 1152 & 1152 & 1152 & 1152 & 1152 & 1152 & 1152 \\
\hline Pseudo $\mathrm{R}^{2}$ & 0.058 & 0.059 & 0.058 & 0.066 & 0.066 & 0.066 & 0.079 \\
\hline $\mathrm{AIC}$ & 2361.5 & 2362.5 & 2363.4 & 2346.4 & 2345.5 & 2344.2 & 2317.5 \\
\hline
\end{tabular}

$+\mathrm{p}<0.1,{ }^{*} \mathrm{p}<0.05, * * \mathrm{p}<0.01, * * * \mathrm{p}<0.001$

Notes: Cell entries are odds ratios with robust standard errors in parentheses. Standard errors are clustered at the village level. 
Table A3: Exploring interplay between education and disaster experience (effects of controls reported)

\begin{tabular}{|c|c|c|c|c|c|c|c|c|}
\hline \multirow[b]{3}{*}{ Years of education } & \multicolumn{4}{|c|}{ Philippines } & \multicolumn{4}{|c|}{ Thailand } \\
\hline & \multicolumn{2}{|c|}{ Preparedness } & \multicolumn{2}{|c|}{ No. of measures } & \multicolumn{2}{|c|}{ Preparedness } & \multicolumn{2}{|c|}{ No. of measures } \\
\hline & $1.087^{*}$ & {$[0.038]$} & $1.085 * *$ & {$[0.031]$} & $1.095 * *$ & {$[0.035]$} & $1.109 * * *$ & {$[0.034]$} \\
\hline Disaster experience & $8.154 * *$ & [5.624] & $4.803 * *$ & [2.573] & $0.933^{*}$ & {$[0.033]$} & $0.924^{*}$ & {$[0.031]$} \\
\hline Interaction & $0.890+$ & {$[0.063]$} & $0.905+$ & [0.047] & $4.797 * * *$ & {$[2.105]$} & $4.807 * * *$ & [2.071] \\
\hline Age group 30-39 & 0.686 & {$[0.243]$} & 0.904 & {$[0.248]$} & $1.628 *$ & [0.339] & 1.384 & {$[0.332]$} \\
\hline Age group 40-49 & 0.914 & {$[0.316]$} & 1.038 & {$[0.250]$} & 1.353 & {$[0.317]$} & 1.23 & {$[0.263]$} \\
\hline Age group 50-59 & 0.856 & {$[0.325]$} & 0.783 & {$[0.214]$} & 0.93 & {$[0.242]$} & 0.868 & [0.207] \\
\hline Age group $\geq 60$ & 0.623 & [0.318] & 0.549 & {$[0.212]$} & 1.16 & {$[0.283]$} & 1.068 & {$[0.243]$} \\
\hline Health status & 1.046 & {$[0.038]$} & $1.061^{*}$ & {$[0.032]$} & 1.082 & {$[0.200]$} & 1.1 & [0.198] \\
\hline Married/Cohabiting & 1.095 & [0.184] & 1.063 & [0.109] & 1.231 & {$[0.273]$} & 1.264 & {$[0.270]$} \\
\hline Currently working & 0.998 & {$[0.295]$} & 1.165 & {$[0.248]$} & 0.769 & {$[0.166]$} & 0.845 & {$[0.160]$} \\
\hline Female & & & & & $1.291+$ & [0.199] & $1.315^{*}$ & {$[0.162]$} \\
\hline Mother has secondary education & 1.073 & {$[0.287]$} & 0.945 & {$[0.176]$} & & & & \\
\hline Father has secondary education & 1.159 & {$[0.242]$} & $1.427^{*}$ & {$[0.247]$} & & & & \\
\hline Started working at age $\leq 12$ & $0.571 *$ & [0.139] & 0.703 & {$[0.164]$} & & & & \\
\hline Household size & $0.880 * *$ & [0.041] & $0.925^{*}$ & {$[0.034]$} & 0.943 & {$[0.043]$} & 0.941 & [0.044] \\
\hline$\%$ children (aged $\leq 5)$ in hh & $1.017 * *$ & {$[0.006]$} & $1.008+$ & {$[0.004]$} & 0.999 & {$[0.006]$} & 0.999 & {$[0.005]$} \\
\hline$\%$ older people (aged $\geq 65$ ) in $\mathrm{hh}$ & 0.997 & [0.011] & 0.994 & {$[0.010]$} & 1.000 & {$[0.006]$} & 0.998 & [0.005] \\
\hline$\%$ with secondary education in hh & 1.008 & {$[0.005]$} & 1.004 & [0.004] & 0.999 & {$[0.002]$} & 0.999 & {$[0.002]$} \\
\hline Years of residence & $1.024 *$ & {$[0.011]$} & 1.008 & {$[0.009]$} & 0.994 & {$[0.005]$} & 0.996 & {$[0.005]$} \\
\hline Own house & & & & & 1.174 & {$[0.313]$} & 1.206 & {$[0.320]$} \\
\hline Own land & & & & & 1.309 & {$[0.273]$} & 1.219 & {$[0.228]$} \\
\hline House located near coast & 0.975 & {$[0.222]$} & 0.941 & {$[0.198]$} & $4.234 * * *$ & {$[1.807]$} & $2.593 * *$ & {$[0.772]$} \\
\hline House located near river & $0.685+$ & {$[0.147]$} & 0.847 & {$[0.152]$} & 0.985 & {$[0.217]$} & 1.000 & [0.202] \\
\hline House located near mountain & $1.789 *$ & {$[0.511]$} & $2.042 * *$ & [0.469] & 1.439 & {$[0.737]$} & 1.657 & [0.890] \\
\hline Area 2 & 1.337 & {$[0.326]$} & 1.36 & {$[0.267]$} & $0.391 *$ & {$[0.177]$} & $0.405^{*}$ & [0.177] \\
\hline Area 3 & 0.975 & [0.222] & 0.941 & [0.198] & 0.979 & {$[0.373]$} & 1.047 & {$[0.388]$} \\
\hline Observations & \multicolumn{2}{|c|}{872} & \multicolumn{2}{|c|}{872} & \multicolumn{2}{|c|}{1152} & \multicolumn{2}{|c|}{1152} \\
\hline Pseudo $\mathrm{R}^{2}$ & \multicolumn{2}{|c|}{0.068} & \multicolumn{2}{|c|}{0.035} & \multicolumn{2}{|c|}{0.115} & \multicolumn{2}{|c|}{0.06} \\
\hline AIC & \multicolumn{2}{|c|}{942.6} & \multicolumn{2}{|c|}{2604.7} & \multicolumn{2}{|c|}{1324.7} & \multicolumn{2}{|c|}{2358.6} \\
\hline
\end{tabular}

$+\mathrm{p}<0.1, * \mathrm{p}<0.05, * * \mathrm{p}<0.01, * * * \mathrm{p}<0.001$.

Notes: Cell entries are odds ratios with robust standard errors in parentheses. Standard errors are clustered at the neighbourhood level $(\mathrm{PH})$ or village level (TH). Dummy variables of whether mother and/or father are unknown (PH) are not displayed. 


\section{VIENNA INSTITUTE OF DEMOGRAPHY}

\section{Working Papers}

Klotz, Johannes and Richard Gisser, Mortality Differentials by Religious Denomination in Vienna 1981-2002, VID Working Paper 8/2015.

Steiber, Nadia and Barbara Haas, Overworked or Underemployed? Actual and Preferred Household Employment Patterns in the Context of the Economic Crisis, VID Working Paper 7/2015.

Beaujouan, Eva, Zuzanna Brzozowska and Krystof Zeman, Childlessness Trends in Twentieth-Century Europe: Limited Link to Growing Educational Attainment, VID Working Paper 6/2015.

Abel, Guy, Estimates of Global Bilateral Migration Flows by Gender between 1960 and 2010, VID Working Paper 5/2015.

Spijker, Jeroen, Alternative Indicators of Population Ageing: An Inventory, VID Working Paper 4/2015.

Kuhn, Michael and Klaus Prettner, Population Structure and Consumption Growth: Evidence from National Transfer Accounts, VID Working Paper 3/2015.

Sobotka, Tomáš, Low Fertility in Austria and the Czech Republic: Gradual Policy Adjustments, VID Working Paper 2/2015.

Buber-Ennser, Isabella, Aspects of Gender Mainstreaming of Family and Work in Austria, VID Working Paper 1/2015.

Buber-Ennser, Isabella and Ralina Panova, Attitudes towards Parental Employment across Europe, in Australia and in Japan, VID Working Paper 5/2014.

Kumar, Abhishek, Valeria Bordone and Raya Muttarak, Influence of Older Generation's Fertility Behaviours on Daughter's Desired Family Size in Bihar, India, VID Working Paper 4/2014.

Sobotka, Tomáš and Éva Beaujouan, Two is Best? The Persistence of a Two-child Family Ideal in Europe, VID Working Paper 3/2014.

Sander, Nikola, Guy J. Abel, Ramon Bauer and Johannes Schmidt, Visualising Migration Flow Data with Circular Plots, VID Working Paper 2/2014.

Barakat, Bilal, Revisiting the History of Fertility Concentration and its Measurement, VID Working Paper 1/2014.

The Vienna Institute of Demography Working Paper Series receives only limited review. Views or opinions expressed herein are entirely those of the authors. 